\title{
Working
}

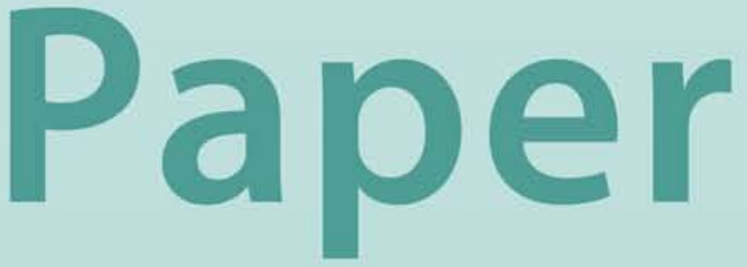




\section{In Finance, Size Matters}

Biagio Bossone and Jong-Kun Lee 


\title{
IMF Working Paper
}

Office of the Executive Director

\author{
In Finance, Size Matters
}

\author{
Prepared by Biagio Bossone and Jong-Kun Lee ${ }^{1}$ \\ Authorized for distribution by Pier Carlo Padoan
}

June 2002

\begin{abstract}
The views expressed in this are those of the author and do not necessarily represent those of the IMF or IMF policy, describe research in progress by the author and are published to elicit comments and to further debate.
\end{abstract}

This study investigates the relationship between production efficiency in financial intermediation and financial system size. The study predicts and tests for the existence of "systemic scale economies" (SSEs), whereby value-maximizing intermediaries operating in large systems are expected to have lower production costs and lower costs of risk absorption and reputation signaling than intermediaries operating in small systems. The study investigates different channels through which the SSEs work their effects through the intermediaries and estimates such effects using a large banking data panel. The study shows strongly supporting evidence in favor of SSEs. It also finds that the institutional environment, the risk environment, and market concentration affect significantly the production efficiency of financial intermediaries.

\section{JEL Classification Numbers: D21; G14; L16}

Keywords: Banks; Financial infrastructure; Financial intermediation; Financial systems; Financial markets; Systemic scale economies

\section{Authors' E-Mail Addresses: Bbossone@imf.org; Jklee@worldbank.org}

\footnotetext{
${ }^{1}$ Biagio Bossone is Advisor to the Executive Director at the International Monetary Fund and is also associated with the Bank of Italy. Jong-Kun Lee is Senior Economist at the World Bank and is also associated with the Bank of Korea. The authors wish to thank G. Dell'Ariccia at the IMF Research Department, A-M. Gulde at the Monetary and Exchange Affairs Department, G. Majnoni, J. Hanson, and P. Honohan for their helpful comments. The opinions expressed in the study are those of the authors only and do not necessarily coincide with those of the colleagues or institutions named above.
} 


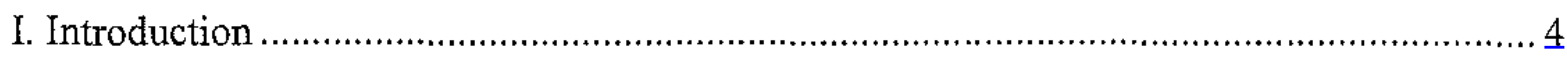

II. Scale Efficiency in Finance: What We Already Know................................................... 5

A. Scale Efficiency in Financial Intermediation............................................................ 5

B. Scale Efficiency in Financial Infrastructure.............................................................. I

III. Scale Efficiency in Finance: What We Want to Know ………...................................... 9

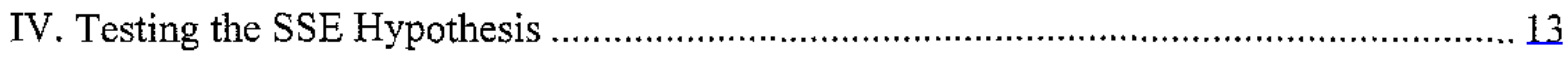

A. Modeling Banks as Value Maximizers ............................................................... 13

B. Estimating the Model .................................................................................. 14

C. Defining and Measuring Scale Economies in Banking.......................................... 16

D. Data and Sources............................................................................................... 17

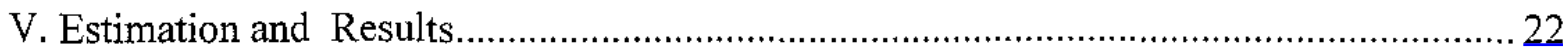

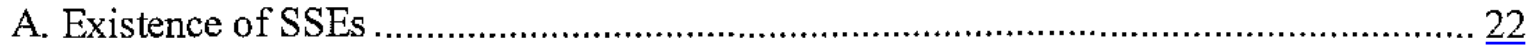

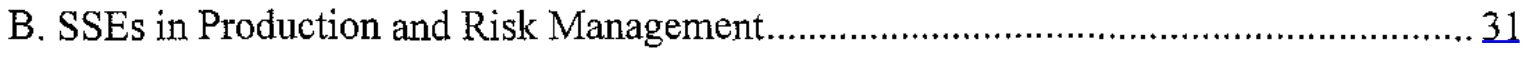

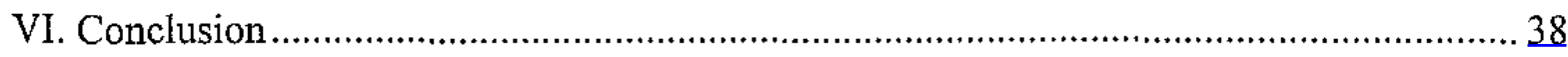

Appendix I: Classification of Countries by Size of their Financial Systems......................... 40

Tables

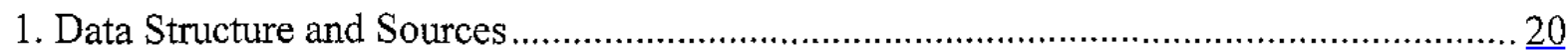

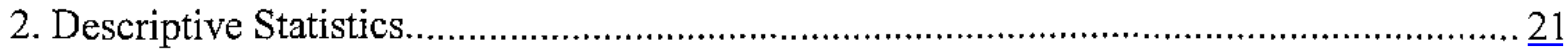

3. Scale Economies and Financial Variables ............................................................... 23

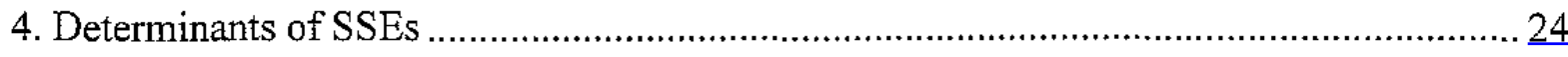

5. Conventional Scale Economies ( $\varepsilon_{V C Q}$ ) by Sizeof Banks and Financial Systems ......... 29

6. Adjusted Scale Economies $\left(\varepsilon_{V C Q}^{q}\right)$ by Size of Banks and Financial Systems ............... $\underline{30}$

7. Average and Marginal Total Cost by Size of Banks and Financial Systems .................... 31

8. Decomposition of Adjusted Scale Economies by Financial System Size ........................... 32

9. SSEs and Technological Change .................................................................................

10. Economies of Capitalization and Financial System Size ............................................ $\frac{35}{36}$

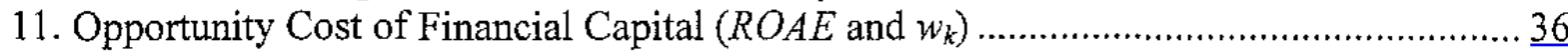

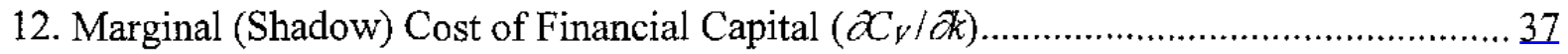

13. Utilization of Financial Capital by Size of Banks and Financial Systems ..................... 38

Figures

1. Relationship Between Scale Economies and Financial System Size …...........................25

2. Relationship Between Scale Economies and Financial Market Size ................................226

3. Relationship Between Scale Economies and Institutional Development .......................... 26

4. Relationship Between Scale Economies and Market Concentration................................ 27

5. Relationship Between Scale Economies and Non-Performing Loans............................. 27 
Boxes

Box 1. Banks and Financial Markets: Supplements or Complements?......................... 28

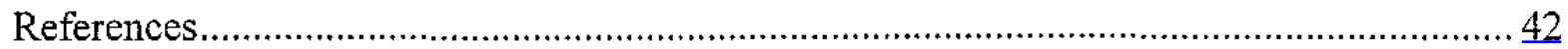




\section{INTRODUCTION}

Many financial systems around the world are small or very small. A recent World Bank study has investigated the economic costs associated with small size in finance, with a view to identifying policies to help countries with small financial systems to minimize these costs (Bossone, Honohan and Long, 2001, here in after referred to as BHL). These costs range from a narrow growth potential for market intermediaries to limited opportunities for risk-pooling and portfolio diversification, to inadequate competition and market incompleteness, to larger transaction and intermediation costs due to the suboptimal scale of financial infrastructure.

Put simply, the assumption underpinning BHL is that small systems typically have small numbers of small institutions, which, in turn, have small numbers of small users. As finance essentially involves increasing returns to scale of various sorts, economies should be expected to bear costs that vary inversely with the size of their financial systems. Evidence from several countries supports the existence of sizeable scale efficiencies both at individual intermediaries and for whole financial infrastructural networks (for example, payment and settlement systems and securities exchanges).

Noting that in modern economies intermediaries increasingly rely on infrastructural networks, BHL also submit that the efficiency of financial intermediation should also reflect the efficiency of networks. In other words, all else being equal, an intermediary of any given size operating in a large domestic financial system should be more efficient than the same intermediary (hypothetically) operating in a smaller system. There might therefore be increasing returns to individual intermediaries from operating in larger-scale systems, implying that intermediaries in small financial systems suffer from the small scale of their operating environment. We refer to such scale effects as "systemic scale economies" (SSEs).

If the hypothesis of the existence of SSEs is supported empirically, the main implication is that intermediaries in small financial systems face greater challenges in achieving market viability than those in larger systems. This has obvious welfare and policy implications, in that access to financial services by users in small financial systems is systematically penalized, unless policies aimed at broadening that access are implemented. Such policy issues are discussed at length in the BHL study, and will not be further elaborated here.

In the attempt to shed evidence on the costs of being small, this study considers various dimensions to the relationship between financial system size and financial production efficiency. In particular, it investigates the existence of scale economies in banking associated with the size of the system in which banks carry out their operations. The study applies state-of the-art cost-analysis techniques on a cross-country and time-series banking data panel in the context of a model where banks are assumed to maximize value, rather than profits, and therefore are sensitive to both first and second moments of their profit distribution function.

The study is organized as follows. Section II updates the reviews of the empirical literature on scale economies in banking and financial infrastructure reported in BHL. 
Section III identifies the channels through which the size of the financial system affects production efficiency in financial intermediation, and formulates in this regard a number of testable propositions. Section IV presents the model and the estimation procedures used in the study, describes alternative measurements of scale economies, and illustrates the data and sources used for the analysis. Section V discusses the results, and Section VI concludes the study.

\section{Scale Efficiency in Finance: What We AlReady Know}

Significant scale economies exist at the level of individual intermediaries and for whole infrastructural systems.

\section{A. Scale Efficiency in Financial Intermediation}

Although economies of scale are integral to the theory of financial intermediation, empirical research has failed for a long time to support the theory's predictions. ${ }^{2}$ Recent studies on banking, however, have uncovered strong scale effects (Berger, Demsetz and Strahan, 1999) and have found that size has efficiency implications also for risk-management and reputation-signaling activities. ${ }^{34}$

Hughes and Mester (1998) detect large economies of scale across all bank sizes and show that, as scale increases, banks economize on the financial capital used to cushion risks and to signal strength to the market, and save on the costs of the (labor and physical capital) resources employed to manage risks and to preserve financial capital. Hughes and Mester also find scale economies in reputation signaling (proxied by the marginal cost of financial capital), which their evidence shows to be significantly lower in the largest banks.

Other studies show that scale efficiency gains derive also from the geographical diversification of risk. In the U.S., the change in scale efficiency reflects the elimination in

${ }^{2}$ Estimations on US bank data in the late 1980s and early 1990s found that the average cost curve had a relatively flat $\mathrm{U}$-shape and that medium-sized banks were only slightly more efficient than both larger and smaller banks. Measured inefficiencies were usually small, on the order of $5 \%$ of costs or less, and efficiency gains petered-out at relatively modest balance sheet sizes and even decreased thereafter. See Berger and others, cit., and the references therein reported, Berger, Hunter and Timme (1993), and Hughes and others (1997). Gropper (1991) reported modest scale economies for US banks over 1979-86, although he found that economies had increased during the observed period likely as a result of regulatory and technological changes.

${ }^{3}$ A larger scale may enhance the potential for risk diversification through a wider mix of financial products and services supplied, as well as via increased geographic spread of activities. McAllister and McManus (1993) first showed that the standard deviation of the rate of return on US bank loans declined rapidly as bank loan portfolios approached $\$ 1 \mathrm{bn}$ in size. However, scale economies from risk diversification may be hidden by the banks' response to a reduced marginal cost of risk by taking on more risk in exchange for higher expected returns (Chong, 1991; Demsetz and Strahan, 1997). Thus, as lower asset quality requires more resources to manage the extra risk, measured scale economies may appear to be lower if the change in asset quality is not controlled for.

${ }^{4}$ Studies of the US banking industry find scale economies on the order of $20 \%$ of costs for bank sizes up to about $\$ 10 \mathrm{bn}$ to $\$ 25 \mathrm{bn}$ in assets (Berger and Mester, 1997) and, contrary to earlier evidence, observe that scale economies increase with the size of banks (De Young, Hughes and Moon, 1998; Hughes 1999). 
1985 of the geographic restrictions on the expansion of bank branching and bank holding companies, which until then had precluded smaller banks from achieving larger and more efficient sizes (Calem, 1994). Hughes and others (1999a) find that the more geographically diversified US bank holding companies have lower deposit volatility, higher expected returns, and lower risk. Hughes and others (1999b) confirm the benefits of geographic diversification using a model that incorporates market-value information on banks. ${ }^{5}$

Evidence of significant scale economies in banking is found across European banking systems, ${ }^{6}$ in Japan (Fukuyama, 1993), Australia (Walker, 1998) and India (Das, 1998). Similarly, international studies on bank categories - characterized, on average, by smaller production units - find strong scale effects. ${ }^{7}$ The fact that this international evidence is based

\footnotetext{
${ }^{5}$ Their analysis shows that an increase in deposit dispersion across states is associated with lower insolvency and profit risks, when the numbers of branching and states as well as the asset size of the bank holding companies are held constant. Moreover, with constant asset size and branch networks, macroeconomic diversification (obtained by weighting deposit dispersion with across-state correlations of macroeconomic activity) is negatively related to both profit risk and insolvency risk. Furthermore, extensiveness of the branch network improves bank profits and lowers insolvency risk. Finally, a proportional increase in assets, branches, deposit dispersion, and macro diversification increases more than proportionally the market value of bank equities and assets, and reduces considerably the market-value equity inefficiency and the market-value asset inefficiency (by a 0.40 elasticity factor). These are interpreted as the dollar amount by which a bank holding companies could increase the market value of its equity (assets) if it were as well positioned in the marketplace, and if it were as efficient, as the best-practice bank holding companies defined by the estimated stochastic riskreturn frontier. The authors conclude that the "benefits of geographic expansion and diversification give banks an important economic incentive to consolidate, especially across state lines." (p. 317).
}

${ }^{6}$ Statistically significant scale economies are found by Altunbas and Molyneux (1996) for French banks up to \$3bn and for Italian banks below \$0.6bn, based on 1988 data. Also 1981-1989 panel data for the 12 largest Italian banks, indicate strongly increasing returns to scale for all banks, especially when the effect of branching is taken into consideration (Parisio, 1992). Parigi and others (1992) confirm these results using panel data for 245 banks (or more than $85 \%$ of the Italian banking system) for the $1985-1989$ period. For Greece Vasiliou (1992) finds a cost/output elasticity coefficient of 0.59 for commercial banks in 1977-1986, and Karafolas and Matakas (1996) show large operating-cost scale coefficients that increase with bank size (from 0.76 to 0.84 ) and over time during the 1908s. A cross-section analysis of Belgian banks for 1988 shows strong scale economies for small institutions, which decrease and change into diseconomies as bank size exceeds $\$ 2.7 \mathrm{bn}$ assets (in 1988 US dollars) and turn into economies again above \$27bn assets (Pallage, 1991). Drake (1992) estimates mild scale economies for UK building societies in 1988 in the $\$ 215 \mathrm{mn}-\$ 890 \mathrm{mn}$ asset range (in 1988 US dollars) and, in contrast to previous evidence, finds no diseconomies of scale for societies above $\$ 2.7 \mathrm{bn}$ assets. Results from a comprehensive sample of credit institutions in the European Community from 1989 to 1991, using data from 800 banks for 1989 and from 1500 banks for 1991, indicate that the minimum cost size of traditional banking activity is situated within the $\$ 3-10 \mathrm{bn}$ asset range (Vander Vennet, 1994). The sample used includes banks from Belgium, Denmark, France, Germany, Italy, Luxembourg, the Netherlands, Portugal, Spain, and the United Kingdom. The study finds that, when output is defined as including loans and deposits, the cost-scale elasticity coefficient varied within $0.85 \%$ and $0.93 \%$, depending on output specification, for banks up to the $\$ 500 \mathrm{mn}$ asset size category and that it approaches one as bank scale moves closer to $\$ 3 \mathrm{bn}$ asset size. The study also analyzes commercial banks and savings institutions separately, and detects stronger efficiency gains for the former group. Further evidence from other studies of scale economies in European banking is reported by Simper (1999). Altunbas and others (2001) find that scale economies are prevalent across EU banking systems (with the exception of the Finnish market). Their estimates show that scale economies, in the order of $5 \%-7 \%$, are widespread both for the smallest banks and for those banks within asset size range of ECU 1 to 5 billions. (Such estimates, however, do not account for hidden scale economies effects due to endogenous risk.)

${ }^{7}$ Rezvanian and others (1996) and Mehdian and Rezvanian (1998) consider the US cooperative banks in the 1989-1991 period. These specialized credit institutions with size averaging about $\$ 80 \mathrm{mn}$ show statistically 
on standard methods suggests that the actual scale efficiency effects may significantly overrun those estimated.

Finally, no evidence (at least, to our knowledge) has been systematically collected and evaluated for banking institutions in small or very small countries, or on a consistent cross-country basis, that would indirectly show the effects of system size on bank efficiency levels (systemic scale effects). Indirect evidence in support of such systemic effect is provided by BHL, who show that bank unit costs decrease with the size of the systems where banks operate, and that bank interest rate spreads are systematically wider in small systems than in large ones.

Evidence on scale economies for non-bank financial intermediaries is much scantier than for banks; yet it shows some consistent indications. Strong scale economies are identified in the French mutual funds industry (Dermine and Röller, 1992), ${ }^{8}$ and in the Japanese securities industry (Fukuyama and Weber, 1999). Evidence of scale efficiency is found in US multi-employer, defined-benefit pension plans (Ghilarducci and Terry, 1999). Information on pension services in Chile suggests that average processing costs may fall to a third of initial costs when the number of members rises (Glaessner and Valdés-Prieto, 1998). Finally, data from a wider spectrum of countries show that economies of scale are present in small multinational insurance companies (up to US2.3bn dollars), while no economies or even diseconomies are detected for larger institutions (Katrishen and Scordies, 1998). ${ }^{9}$

\section{B. Scale Efficiency in Financial Infrastructure}

Recent studies confirm that infrastructures such as payment systems and organized securities markets have increasing returns to scale. Preliminary evidence also detects scale economies in regulatory systems.

significant economies of scale for each class size and across the various sub-periods considered. Such economies seem to have increased over time, although constant returns are observed for banks with asset size greater than $\$ 100 \mathrm{mn}$. Similar findings hold for cooperative banks in Germany (Lang and Welzel, 1996) and for savings banks in Italy (Simper, 1999). Zardkoohi and Kolari (1994) analyze 615 branches of 43 Finnish savings banks in 1988 and find that relatively large branch offices tend to operate more efficiently than small branches, with economies ranging from 0.78 to 0.95 and exhausting at $\$ 61 \mathrm{mn}$ asset size. Evidence supporting scale economies has also been found for small and medium size savings and loan associations (Le Compte and Smith, 1990) and for credit unions (Kohers and Mullis, 1988; Fried and others, 1993).

${ }^{8}$ The cost/output elasticity is 0.69 for firms up to about $\$ 200 \mathrm{mn}$ and 0.89 for firms in the range $\$ 200 \mathrm{mn}$ $\$ 500 \mathrm{mn}$ range.

${ }^{9}$ Their sample covers 93 insurers from 15 countries and operating in at least one foreign country, for the years 1985 through 1992 . The estimated clasticity for the sub-samples with mean premium of $\$ 0.2 \mathrm{bn}, \$ 1.5 \mathrm{bn}$, and $\$ 2,3 \mathrm{bn}$ is $0.66 \%, 0.78 \%$, and $0.85 \%$, respectively, while it approaches unity for firms with mean premium income of $\$ 4.9 \mathrm{bn}$. Other studies find economies of scale up to $\$ 15 \mathrm{bn}$ in assets, and constant or decreasing returns thereafter (see Suret, 1991, Fecher et al. 1992, and Cummins and Weiss, 1993). From a sample of 223 life and non-life Italian insurers for 1987 (excluding those below about \$0.62 million premium sales, in 1987 US dollars), Focarelli (1992) estimates very strong economies for the largest firms, but only modest scale economies for all the remaining size sub-samples considered. 
Hancock and others (1999) find significant economies of scale in payment system data processing. ${ }^{10}$ They report the results from studies of the cost structure of the Automated Clearing House (ACH) electronic transfers in the United States, ${ }^{11}$ and cite evidence from a study of the Federal Reserve's electronic book-entry government securities transfer system (Belton, 1984). Payment systems are characterized also by network externalities (Saloner and Shepard, 1995; Gowrisankaran and Stavins, 1999).

As regards organized securities markets, evidence supports the existence of significant scale efficiency effects both in trading operations and in firm-specific information processing activities (listing), and indicates that cost effectiveness of stock exchanges is higher where regulation is more homogeneous (Malkamäki 1999; Hasan and Malkamäki 2001). Stock exchange transaction costs decline sharply relative to the transaction value as the size of transaction grows, even in advanced markets (Green, Maggioni and Mwunde, 2000). Network effects, too, are present in organized markets (Cybo-Ottone, Di Noia and Murgia, 1999).

Finally, there are indications that scale economies characterize regulatory systems as well. Country survey data on the cost to the public authorities of providing banking regulation and supervision indicate that such costs increase less than proportionately with the size of the system (BHL). ${ }^{12}$ In fact, actual spending may be less than optimal and the

\footnotetext{
${ }^{10}$ The decreasing cost of installing a centralized data processing site has been at the origin of the various consolidations observed in the US payment system from 1979 to 1996. Consolidations have involved reduction of data processing sites, reduction of customer service offices, standardization of automation programs at the Reserve Banks. The costs saved by consolidating data processing exceeded the increased spending on telecommunications inputs; as a result, reported average cost savings in real terms were on the order of $60 \%$ and an average scale cost elasticity of one-half was found.

${ }^{11}$ The ACHs are electronic clearing systems in which payment orders are exchanged among financial, primarily via magnetic media or telecommunications networks, and handled by a data processing center. They deliver mass payments, that is, large amounts of small-value payments to or from individuals. The most recent study (Bauer and Ferrier, 1996) shows that a 10\% increase in the volume of $\mathrm{ACH}$ payments processed is associated with only a $4.8 \%$ increase in production costs, suggesting that the average cost curve for ACH transfers production is strongly downward sloping, as opposed to the L-shaped curve for check payment processing.

${ }^{12}$ There are, of course, also private compliance costs, which are generally thought to be much higher than the official cost (one rule of thumb is that private costs can be four times those incurred by the regulator), but they are less likely to be subject to economies of scale. See Franks and others (1998) who estimated incremental costs for securities firms in the UK at $£ 1854$ per financial sector employee, a figure which was broadly consistent within the range of 6-14\% of non-interest expenses found by Hopkins (1992) for US banking.

${ }^{13} \mathrm{~A} \log$ regression of costs on $\mathrm{M} 2$ gives an estimated elasticity of 0.689 , with a standard error of 0.087 , implying considerable economies of scale. According to the equation, ten economies, each with an M2 of $\$ 1$ billion will have more than twice the regulatory costs of a single $\$ 10$ billion economy. The projected aggregate regulatory costs of the 100 smallest financial systems, at $\$ 53$ million per annum, are almost $\$ 20$ million higher than they would be if regulatory costs were proportional to those of a $\$ 10$ billion economy. The source of data is the regulatory survey in Barth, Caprio, and Levine (2000). Of course this is based on the actual, not necessarily optimal, level of spending.
} 
shortfall may in fact be greater for smaller systems. ${ }^{14}$ If so, the effective scale economies in supervision are likely to be larger than those indicated by the actual data. ${ }^{15}$

\section{Scale EfFiciency in Finance: What We Want to Know}

The literature on scale economies in finance, and especially the most recent studies carried out at the firm level and for whole infrastructural networks, suggest that production efficiency in financial intermediation should reflect not only the production scale of the individual intermediary, but also the size of the financial system where the intermediary operates (the SSE hypothesis). Some of the studies reviewed, in particular, place special emphasis on scale efficiency effects relating to risk-management functions. This section identifies the channels through which the size of the financial system affects production and risk-management efficiency in financial intermediation, and formulates two testable propositions. This section and the following focus on the banking industry, but the arguments and the empirical analysis can be generalized to the production of nonbank financial intermediation services.

Identifying and testing the SSE channels build on the new literature on scale economies in bank production (reviewed in Section II) since the path-breaking contribution by McAllister and McManus (1993). ${ }^{16}$ Two features from this literature are crucial to our study: one is that risk taking in bank production is endogenous; the other is that banks maximize value (rather than profits). The implications of these two features for our study are the following.

As regards the first feature, the estimation of bank scale efficiency must control for the impact of endogenous risk decisions on costs: if an increase in system size reduces the marginal cost of risk taking for individual banks, and hence raises the banks' marginal return on risk taking, the banks have an incentive to take on additional risks, that is, to reduce their asset quality in the expectation of getting higher returns. However, since higher risks generate additional risk-management costs (including higher financial capital, more inputs, and higher risk premiums on borrowed funds), the banks may actually use up (part of) the initial cost savings. As a result, estimates that did not duly account for risk endogeneity would not capture the cost effects of scale.

\footnotetext{
${ }^{14}$ In particular, the policy capacity of a small regulatory system is likely to be more easily swamped by a large disturbance, and there is some indication that the cost of banking crises may have been disproportionately larger in small countries (Honohan, 2000).

${ }^{15}$ Other aspects of financial policy are also subject to economies of scale, including monetary policy formulation, the cost of issuing and maintaining the circulation of currency notes and the operation of a payments system.

${ }^{16}$ As rccalled, McAllister and McManus showed that the standard deviation of the rate of return on bank loan portfolios falls dramatically as the size of the portfolios increases up to a level, presumably due to diversification effects. Such risk reduction lowers the amount of physical and financial resources that banks need to manage their risk exposures.
} 
As for the bank objective function, the profit-maximization (cost-minimization) objective assumed in the standard models used to measure bank production efficiency may be inappropriate. Since risks create the potential for costly episodes of financial distress, banks seek to maximize value and are prepared to trade higher profit for lower risk. By incorrectly assuming profit-maximization, standard models may fail to detect the responsiveness of the bank risk/return tradeoff to scale effects: risk-averse bankers may find the level of financial capital implied by profit to be unacceptably low. Their demand for capital would have to be modeled by a broader objective than profit maximization. ${ }^{17}$ However, high market concentration or a too-large-to-fail type of expectations may reduce the perceived riskiness of individual banks (at least of the dominant ones) and may weaken their incentive to accumulate financial capital in the face of given levels of risk. Failing to control for market concentration would therefore lead to biased estimations of systemic scale externalities.

Both these aspects are incorporated in the methodology used in the next section to test the SSE hypothesis. This hypothesis can be translated into the following two operational propositions.

Proposition 1: SSEs in Production. All else being equal, banks operating in larger financial systems have relatively lower production costs than banks operating in smaller systems.

If the scale efficiency effects incorporated in financial infrastructural services (Section II.B) feed back into bank production (independently of the bank-specific production cost structure), the average production cost should be expected to be higher (lower) for banks operating in small (large) systems, and to decrease with the size of the financial system where the banks operate. As an example, a larger payment system, a larger bank credit bureau, or a larger infrastructure for the dissemination of financial information should offer less expensive (implicit or explicit) service charges to accessing banks, and should thereby afford banks a lower production costs than if they used smaller infrastructure.

Also, since banks need to raise their financial capital when expanding production, larger financial systems should allow them to economize on capital resources by diversifying their asset portfolio more efficiently across a broader borrower base, a wider spectrum of activity sectors, and different geographic areas. As a result, an increase in the output of banks operating in larger systems should require proportionately less financial capital than that of banks in smaller systems.

Finally, the cost structure of the banks should be expected to change differently over time, in response to changes in the technology embodied in financial infrastructure, depending on the size of the financial system in which they operate. Banks operating in larger financial systems should benefit more rapidly from technological developments that

\footnotetext{
${ }^{17}$ For a thorough discussion of these issues and their applications, see Hughes and others $(1997,2001)$, Hughes
} (1999). 
improve the efficiency of infrastructural services used as production inputs. ${ }^{18}$ This effect should be measured by observing a more (less) rapid pace of cost decline for banks operating in larger (smaller) systems. The more rapid decline would be caused by the interaction between network externalities and scale economies that typically characterize infrastructural network services (see Section II.B).

The types of SSEs in production just discussed derive from the absolute scale of the financial system (as opposed to the SSE effects associated with the size of the financial system relative to that of the economy; see Proposition 2 below). Therefore, a level variable should be used in an empirical cross-sectional comparative analysis. This level variable should also include information on the degree of openness of the system to international transactions, as this would reflect the extent to which the domestic financial system is integrated into (wider) international financial infrastructural networks.

Proposition 2: SSEs in Risk Management. All other things being equal, banks that operate in larger financial markets have relatively lower costs of risk absorption and reputation signaling than banks operating in smaller financial markets.

Banks use financial capital as a buffer against risks and as a device to signal their financial soundness to the market. As Hughes and Mester (1998) note, given the observable scale and asset quality of a bank, an increase in its financial capital reduces the likelihood of insolvency and provides an incentive to allocate additional resources to risk-management activities aimed to protect the larger equity stake. Also, a higher degree of capitalization (for given observable scale and asset quality) signals the greater safety of the bank and enhances its market reputation. Therefore, in competitive markets banks need to accumulate more financial capital than if they faced less competition.

Yet a bank's demand for financial capital should be expected to grow less than proportionately than the size of the financial markets where the bank operates, for a number of reasons:

- First, deeper and more efficient financial markets help banks to improve their screening of potential borrowers, ${ }^{19}$ to monitor their investment more efficiently, and to signal their risk attitude through information other than (and possibly complementary to) accumulated financial capital. As a result, banks operating in large systems should attain

${ }^{18}$ When the same technology development takes place in two network systems that hypothetically differ in size only, the network externalities in the larger system are stronger because the larger size attracts more users; more users mean larger economies of scale and lower service charges, which in turn generate additional network economies. The reduction in production cost and service charges per time unit would be larger in the larger system.

19 This effect rests on the assumption that banks use capital market information like other non-bank investors. As stock markets aggregate (and reflect on prices) the views of a wide range of different investors (Allen and Gale, 1999), they provide "multiple checks" on individual firms and, hence, the best indicators possible of the true value of the firms. 
the same degree of protection against financial distress and the same reputation signaling effect with a lower capital-to-asset ratio than those operating in smaller systems. As an implication, banks in small (large) systems should over- (under-)utilize financial capital.

- Second, deeper and more efficient financial markets should enable banks to manage and protect their financial capital with relatively less non-financial resources. More specifically, as banks increase their output and adjust their financial capital position accordingly, they may need to mobilize additional (non-financial) resources to manage and protect their financial capital. The presence of SSEs should imply that banks operating in larger financial systems should perform these functions with relatively fewer non-financial resources than those operating in smaller systems. For example, the availability of better information provision and more efficient contract enforcement systems may allow banks to economize on additional human resources needed to manage increase in risk positions.

- Third, with better information provision (meaning more and higher-quality information) and higher signal-extraction capacity by investors, signaling becomes more efficient and banks can economize on the financial capital needed to signal a given level of reputation or risk safety. The same holds if investors can rely on greater regulatory and rule enforcement capacity.

- Fourth, with better information provision and higher signal-extraction capacity, banks operating in larger and more efficient financial markets should be able to raise new financial capital at a less than proportional increase in the cost of capital since, all else being equal, achieving a higher level of capital would signal a stronger position vis-à-vis risks.

Investigating empirically the SSE channels implied by Proposition 2 suggests the use of a relative size indicator, as financial market depth and efficiency are better proxied by variables that measure the scale of the markets relative to the size of the overall economy.

Propositions 1 and 2 can be summarized saying that larger financial systems enable intermediaries to lower their (average and marginal) resource costs for managing risks, and that deeper financial markets enable them to increase the efficiency of their risk-management capacity.

The two propositions, taken together, imply that in larger and more efficient financial systems the minimum efficient bank size should be smaller (all else being equal). The development of financial infrastructure should in principle allow all banks to gain efficiency across all classes of system size. All else equal, a reduction in average production costs across all system size classes increases the profitability of all banks and induces new market entry from the set of infra-marginal banks: if production at the bank level shows increasing returns relating to SSEs, small banks that were unprofitable in systems with small and inefficient infrastructure would become viable once they can have access to larger and more 
efficient infrastructure. They can therefore enter the market and be able to survive. Putting this third proposition to test will be the subject of future work. ${ }^{20}$

\section{TESTING THE SSE HYPothesIS}

\section{A. Modeling Banks as Value Maximizers}

Following Hughes and Mester (1998) and Hughes, Mester, and Moon (2001), who use a value-maximizing cost function instead of a conventional cost function, ${ }^{21}$ we use a restricted-variable cost function approach, conditioned on the level of financial capital and risk-related asset quality. Assuming the intermediation hypothesis (like in most banking cost function studies), which regards deposits ( $d$ ) as inputs to production, the restricted-variable cost function $\left(C_{V}\right)$ is derived from the cost minimization problem subject to the quasi-fixed input of equity capital $\left(k=k^{0}\right)$ as a conditioning argument. In addition, we amend the shortrun variable cost function, $C_{V}$, by adding an appropriate control variable $(\phi)$ for capturing country-specific financial sector features in each country observed and a proxy variable for technological progress $(t)$. Note that the underlying model specification incorporates the risk endogeneity effect by including the response of financial capital to changes in asset quality $(q)$, discussed in section III. Then, $C_{V}$, which can be viewed as a cash-flow cost function, ${ }^{22}$ is defined as

$$
C_{V}\left(Q, w_{p}, w_{d}, k, q, \phi, t\right)=\min \left(w_{p} x_{p}+w_{d} x_{d}\right) \text { s.t. } T(Q, x, k: q, \phi, t) \leq 0 \text { and } k=k^{0}
$$

where

$C_{V}=$ variable cost function corresponding to variable cost $\left(V C=w_{p} x_{p}+w_{d} x_{d}\right)$

$T(\cdot)=$ transformation function

$Q=$ output (total loans and other earning assets)

$w_{p}=$ price of physical inputs (labor $(l)$ and physical capital $(c)$ )

$w_{d}=$ price of deposits $(d)$

${ }^{20}$ Interesting implications of this proposition are that $i$ ) the minimum size for a bank to be viable depends on the structure (that is, scale, sector composition, and efficiency) of the financial systems where they operate, and that $i$ ) the economic costs of financial intermediation vary inversely with the size of the financial system. The intuition behind the proposition is not new in the literature. It underpins the proposal by Honohan and Kinsella (1982) to measure bank concentration across countries by using a variant of the Herfindhal index, where the index is normalized by a minimum feasible value based on the size of the bank market of each country. Assuming increasing return to scale in bank production, Honohan and Kinsella found that the maximum feasible number of banks (that is, consistent with non-negative profits) is roughly proportional to the square root of the bank market size.

21 For bank managers who are not risk neutral, maximizing value (as against profits) implies that they are willing to trade profit for reduced risk. They therefore attribute a positive value to guarding against financial distress and the need to signal their bank's safety by choosing a level of capitalization that likely exceeds the cost-minimizing level.

${ }^{22}$ According to Hughes, Mester and Moon (2001), the cash-flow cost function is defined as the minimum operating cost function $\left(w_{p} x_{p}\right)$ plus the cost of debt $\left(w_{d} x_{d}\right)$. The minimum economic cost function includes the cost of financial capital $\left(w_{k} k\right)$ in addition to the cash flow cost function. 
$x=$ quantity of variable factor input $\left(=x_{p}+x_{d}\right)$

$k=$ financial (equity) capital

$q=$ asset quality (ex post and ex ante measure of risk factors)

$\phi=$ control variables for financial structural and institutional factors

$t=$ a state of banking technology at time t.

The bank's value-maximizing problem is to minimize the economic cost resulting from the sum of the cash-flow cost in the short-run and the additional opportunity cost of equity capital at the given time of evaluation. Thus, the long-run (total) economic cost function $\left(C_{T}\right)$ is specified as

$$
C_{T}\left(Q, w_{p}, w_{d}, w_{k}^{*}, q, \phi, t\right)=C_{V}\left(Q, w_{p}, w_{d}, k, q, \phi, t\right)+w_{k}^{*} k
$$

where

$w_{k}=$ market (equilibrium) rental price of financial capital

$w^{*}{ }_{k}=$ shadow price of financial capital $\left(=-\partial C_{V} / \partial k\right)$.

Since it is generally difficult to obtain $w_{k}$ upon empirical estimation of a long-run (equilibrium) total cost function, the shadow price of capital $\left(w^{*}\right)$ has been frequently used as a substitute for the market rental price of capital $\left(w_{k}\right)$ in the literature. Note that $w_{k}=w_{k}^{*}$ in the long-run equilibrium. However, in the short-run, the shadow price tends to deviate from the market rental price, implying an over- (or under-) utilization of capital to optimize the use of quasi-fixed input of capital at the given market (equilibrium) rental price of capital (i.e., $w_{k}+\partial C_{V} / \partial k>0$ or $<0$ ).

A dynamic factor demand system can thus be set up, which consists of a restricted variable cost function (Eq. 3), share equations for variable factors (Eq. 4), and the equation for the quasi-fixed factor (Eq. 5) which incorporates the shadow price of capital equation

$$
\begin{aligned}
& C_{V}=C_{V}\left(Q, w_{p}, w_{d}, k, q, \phi, t\right) \equiv V C=\Sigma w_{j} x_{j}, j=p, d \\
& S_{j}\left(=\frac{w_{j} x_{j}}{V C}\right)=\frac{\partial \ln C_{V}}{\partial \ln w_{j}}, \Sigma S_{j}(>0)=1, j=p, d \\
& S_{k}\left(\equiv \frac{V C-P Q}{V C}\right)=\frac{\partial \ln C_{V}}{\partial \ln k}(<0)
\end{aligned}
$$

\section{B. Estimating the Model}

To estimate the dynamic factor demand system (3)-(5) with the conditional variable cost function $\left(C_{V}\right)$ in Eq. (3), we use the translog functional form ${ }^{23}$

\footnotetext{
${ }^{23}$ See Hughes and Mester (1998, p. 320) for a detailed translog model specification with symmetry and linear homogeneity restrictions imposed upon empirical implementation.
} 


$$
\ln V C=\alpha_{0}+\sum_{i} \alpha_{i} \ln Z_{i}+\frac{1}{2} \sum_{i} \sum_{j} \beta_{i j} \ln Z_{i} \ln Z_{j},
$$

where $Z=\left(Q, w_{l}, w_{d}, w_{c}, k, t, q a, F S, F S D\right)$.

$Q$ : single aggregate output

$w_{j}$ : variable factor prices for labor $(l)$, deposits $(d)$, and physical capital $(c)$

$k$ : financial (equity) capital

$t$ : time trend variable representing technological progress

$q a$ : asset quality (adjusted non-performing loan ratio $=$ NPL/Accounting Standards)

$F S$ : (absolute) financial system size (in US billion dollars)

$F S D$ : (relative) financial system depth $\left(F S / G D P{ }^{*} M S\right)$

$M S=$ financial market size

Then, variable factor share equations $\left(S_{j}\right)$ and one shadow price equation $\left(w_{k}\right)$ can be directly derived from (Eq. 6), by differentiating $C_{V}$ with respect to variable factor prices ( $w_{l}$, $\left.w_{d}, w_{c}\right)$ and quasi-fixed factor input of equity capital $(k)$. With symmetry $\left(\beta_{i j}=\beta_{j i}\right)$ and linear homogeneity imposed, the derived equations are expressed as follows

$$
\begin{aligned}
& S_{j}=\alpha_{j}+\sum_{i} \beta_{i j} \ln Z_{i}, j=l, d, c, \Sigma S_{j}=1 \\
& w_{k}=-\partial C_{V} / \partial k=\left(\alpha_{k}+\sum_{i} \beta_{i k} \ln Z_{i}\right) \frac{V C}{k}
\end{aligned}
$$

Like in Hughes and Mester (1998), we explicitly specified the financial capital demand equation to capture the endogeneity of financial capital in association with riskrelated asset quality

$$
\ln k=\gamma_{0}+\gamma_{1} \ln Q+\gamma_{2} \ln F S+\gamma_{3} \ln F S D+\gamma_{4} \ln C N+\gamma_{5} \ln q a+\gamma_{6} \ln R+\gamma_{7} \ln \Pi
$$

where

$C N$ : banking market concentration $(0 \leq C N \leq 1)$

$R$ : liquidity asset ratio

$\Pi$ : profitability (spread between loan and deposit interest rates)

After substituting equation (9) into (6), (7) and (8), we estimated system equations of factor demand, consisting of the restricted variable cost function (Eq. (6)), two share equations (out of three) for variable inputs (Eq. (7)), ${ }^{24}$ and the shadow price of equity capital equation (Eq. (8)). Upon empirical estimation, the intercept terms $\alpha_{0}$ in (6) and $\gamma_{1}$ in (9) are allowed to vary across countries to mitigate the heterogeneity of the underlying sample, thus enabling us to take account of country-specific differences. The model is estimated simultaneously by applying an iterative seemingly unrelated regression (SUR) estimation

${ }^{24}$ Since the variable input cost-share equations sum to unity, the share equation for physical capital $\left(S_{c}\right)$ was deleted from the estimated system of equations. See Berndt and others (1974) for details. 
technique. The estimates obtained are asymptotically equivalent to maximum likelihood estimates. The estimation results for pooled cross-section time series are not shown here, ${ }^{25}$ but most of the parameter estimates are statistically significant at the $5 \%$ level. The $R^{2}$, s in the system equation regressions are high, showing an acceptable goodness-of-fit. ${ }^{26}$

\section{Defining and Measuring Scale Economies in Banking}

Once a translog cost function is explicitly specified, we can derive parametric estimates of scale economies. We use four measures of scale economies $\left(\varepsilon_{C Q}\right)$, defined as follows. Note that, in the following, $\varepsilon_{C Q}>1$ implies economies of scale (i.e., less proportionate increase in $C$ with respect to changes in $Q \Rightarrow \partial \ln C / \partial \ln Q<1$ ), whereas $\varepsilon_{C Q}<1$ implies diseconomies of scale.

\section{(1) Conventional Measure of Scale Economies in $C_{V}$}

When a multi product cost function $\left(Q=\left(Q_{1}, Q_{2}, \ldots, Q_{n}\right)\right)$ is assumed, the Conventional Measure of Scale Economies is defined as

$$
\varepsilon_{V C Q}=\frac{1}{\sum_{i}^{n} \frac{\partial \ln C_{V}}{\partial \ln Q_{i}}}
$$

which shows how cost changes in proportion to output variations. It must be noted that estimating Eq. (10) from system (6)-(9) allows us to control for asset quality and the changes in variable cost associated with risk management. This measure of scaleeconomies, therefore, reflects the effects of output on production net of cost changes due to endogenous risk if a scaled variation in $Q$ and $q$ in $C_{V}$ is considered.

\section{(2) Quality-Adjusted Measure of Scale Economies in $C_{V}$}

Following Hughes and Mester (1998), the Quality-adjusted Measure of Scale Economies is derived by holding asset quality $(q)$ constant

$$
\varepsilon_{V C Q}^{q}=\frac{1}{\sum_{i}^{n} \frac{\partial \ln C_{V}}{\partial \ln Q_{i}}+\left(\sum_{i}^{n} \frac{\partial \ln C_{V}}{\partial \ln k} \frac{\partial \ln k}{\partial \ln Q_{i}}+\frac{\partial \ln C_{V}}{\partial \ln q}+\frac{\partial \ln C_{V}}{\partial \ln k} \frac{\partial \ln k}{\partial \ln q}\right)}
$$

By taking into account the endogeneity of risk and financial capital, this parametric measure will reflect the effect on cost of a proportionate variation in the levels of output and non-performing loans taken as a proxy for risk-related asset quality; it therefore captures the full effect on cost of both output and risk changes. Estimating the individual components of

${ }^{25}$ Detailed parameter estimates are available from authors upon request.

${ }^{26} R^{2}: 0.972$ for variable cost equation, 0.392 for labor cost-share equation, 0.405 for deposit cost-share equation and 0.176 for shadow price of financial capital equation. The log of likelihood functions is computed as 6809.86 over 2625 total sample observations. 
the denominator of (Eq. 11) provides further insights on the differential impact of various sources of SSEs.

\section{(3) Economic-cost Scale Economies in $C_{T}$}

Following Hughes, Mester and Moon (2001), who use a shadow valuation of financial capital, the measure of the Economic-cost Scale Economies from a shadow total cost function is given by

$$
\begin{aligned}
& \varepsilon_{T C Q}=\frac{1}{\left[\partial C_{T}\left(Q, w_{p}, w_{d}, w_{k}^{*}, q, \phi, t\right) / \partial Q\right] \cdot\left[Q / C_{T}\left(Q, w_{p}, w_{d}, w_{k}^{*}, q, \phi, t\right)\right]} \\
& =\frac{1}{\left[\partial C_{V}\left(Q, w_{p}, w_{d}, k, q, \phi, t\right) / \partial Q\right] \cdot\left[Q /\left(C_{V}\left(Q, w_{p}, w_{d}, k, q, \phi, t\right)+\left(-\partial C_{V} / \partial k\right) k\right)\right]} \\
& =\frac{1-\frac{\partial \ln C_{V}}{\partial \ln k}}{\sum_{i} \frac{\partial \ln C_{V}}{\partial \ln Q_{i}}}=\varepsilon_{V C Q}\left(1-\frac{\partial \ln C_{V}}{\partial \ln k}\right)
\end{aligned}
$$

where $C_{T}$ is the economic total cost function, defined as the sum of variable $\operatorname{cost}\left(C_{Y}\right)$ and the shadow cost of financial capital $\left(\left(-\partial C_{V} / \partial k\right) k\right)$ taken as a substitute for its market price value. This specification allows to measure scale economies taking into account the economic impact of the demand for financial capital on variable cost. ${ }^{27}$

\section{(4) Economic-cost and Quality-adjusted Scale Economies in $C_{T}$}

Finally, combining Eqs. (11) and (12) yields the new comprehensive measure of adjusted scale economies in the total cost function

$$
\varepsilon_{T C Q}^{q}=\varepsilon_{V C Q}^{q}\left(1-\frac{\partial \ln C_{V}}{\partial \ln k}\right)
$$

which incorporates the asset-quality control feature into the total (economic) cost structure of bank production

\section{Data and Sources}

A sample of 875 commercial banks from 75 countries was drawn mainly from the IBCA's (2000) BankScope database, which contains banking information for over 1900 commercial banks with more than 1 billion US dollars in total asset size. A total sample of 875 banks was almost equally divided into three subgroups according to the reported total

${ }^{27}$ It is economic because the (total) cost is minimized over the cash-flow (variable) cost and the opportunity (or shadow) cost of financial capital. 
asset size: ${ }^{28}$ small banks (292 banks, smaller than 2.4 billion US dollars), medium banks ( 292 banks, between 2.4 and 8.0 billion US dollars), and large banks ( 291 banks, larger than 8.0 billion US dollar). Since a complete set of variables is required for the analysis of the bank cost structure, almost half of the banking observations for which information was partially missing or misreported had to be dropped. In those cases where the necessary banking data were not available on BankScope, we referred directly to banks' financial statements (available on the official website) or, as an alternative or complementary source, to official reports on domestic banking from national financial supervisory authorities.

In the case of missing information for some important variables in the BankScope database, average values of peer-group banks in each country were used instead. To collect comparable international data from different countries, we simplified the data structure by aggregating variables that for some countries were not available on a disaggregated basis, and by removing some country-specific banks from the sample. The data were extracted from non-consolidated income statements and balance sheets, ranging from 1995-1997. All banking data (except quantity variables) are reported in US dollars and are adjusted for CPI inflation in each respective country. ${ }^{29}$ The resulting data is a pooled sample of crosssectional time series of 2,625 observations over the three years considered (i.e., 875 observations for each year).

Following the intermediation approach to estimate economies of scale in banking, our main specification for the bank's cost function is characterized by one single output and four inputs. Output $(Q)$ is defined as the sum of total loans and other earning assets, which are measured as the average dollar amount at the end of each year; the corresponding output price $(P)$ is calculated by dividing the total interest revenue by the inflation-adjusted total earning asset. The inputs are: two non-financial factor inputs, labor $\left(x_{l}\right)$ and physical capital $\left(x_{c}\right)$; and two financial inputs, deposits $\left(x_{d}\right)$ and financial (or equity) capital $(k)$.

The price of labor $\left(w_{l}\right)$ is obtained by dividing total salaries and benefits paid by the total number of employees. The price of physical capital $\left(w_{c}\right)$ is derived as the ratio of other operating expenses, including occupancy expenses, over inflation-adjusted fixed assets $\left(x_{c}\right)$. Since other operating expenses reported by BankScope include other non-interest expenses, this may lead to overestimating the actual price of physical capital. However, the data seem to be relatively consistent across countries in that information disclosure and accounting standards are identical for all banks. On the other hand, the input price of deposits $\left(w_{d}\right)$ is obtained by dividing total interest expenses by the total inflation-adjusted amount of deposits $\left(x_{d}\right)$. The input quantity of financial capital $(k)$ was directly obtained from the inflationadjusted figure for equity capital reported in the balance sheets. However, since no information was available on the cost of financial capital, the return on average equity $(R O A E)$ and an estimate of the market rental price of capital based on the bank production

${ }^{28}$ Average total assets, in terms of inflation-adjusted billions of US dollar, during 1995-1997 time period in the sample was estimated at 19.4 .

${ }^{29}$ For cross-country comparability we directly used inflation-adjusted values - whenever applicable - which are also available in the BankScope database. 
function were used as proxies for the price of financial capital $\left(w_{k}\right)$ reflecting the opportunity cost of equity capital. We shall return to this point in Section V.B.

In addition to these micro, bank-specific data, macro country-specific variables were used to control for the effects of various financial-sector structural characteristics and for the different level of financial sector development in each country. The information was mainly obtained from the World Bank's Global Development Finance (2001a, GDF) and World Development Indicators (2001b, hereafter WDI) and the IMF's International Financial Statistics (IFS), and the databases from Beck, Demirgüç-Kunt and Levine (1999, hereafter BDL) and from La Porta and others (1997 and 1998, hereafter LLSV).

As for the absolute size of the financial system of each country $(F S)$, we constructed a comprehensive indicator for open economies by summing domestic credit, domestic deposits, foreign assets, and foreign liabilities of the banking system, expressed in US billion dollars. $^{30}$ We then divided the overall 75 -country sample into three financial system size subgroups: ${ }^{31}$ Small systems ( $F S<U S 35 b n ; 24$ countries), Medium systems (US35bn $<F S<\mathrm{US} 300$ bn; 25 countries), and Large systems ( $F S>\mathrm{US} 300 \mathrm{bn} ; 23$ countries). A detailed classification of the sampled countries is reported in Appendix A.

To capture the relative size of the financial system, we used the FSD ratio (= $F S / G D P$ ) as a proxy for financial depth. We also constructed a composite size indicator of domestic capital markets $(M S)$ by multiplying the three stock market ratios reported in BDL (1999): stock market capitalization to $G D P$, stock market total value traded to $G D P$, and stock market turnover to GDP. Note that since the indicator reflects the relative size of the market and includes the turnover ratio, it captures both the depth and the efficiency of the domestic capital markets.

Finally, we used the accounting standard index $(A S)$, from LLSV (1998), as a proxy for information transparency, and also constructed a composite index (INST) for institutionsrelated variables. ${ }^{32}$ To capture the different asset quality of banks across sample countries, we used the ratio of non-performing loans $(N P L)$ to total assets for each bank, corrected for the different accounting standards in each country, so that poorer accounting standards translate into higher values of the adjusted $N P L$ ratio (NPL ratio/Accounting Standards Index).

${ }^{30}$ Although these indicators include only banking variables, they should indirectly reflect also the size of some of the main infrastructural components underpinning the financial system (e.g., payment and clearing systems, legal/regulatory/supervisory systems, information systems and services, liquidity facilities and safety nets, etc.)

${ }^{31}$ We had initially considered to included a fourth subgroup of three very small open economies, namely, Bermuda, Liechtenstein, and Monaco, whose $F S$ is assumedly less than 1 billion US dollars. Since the official monetary statistics for these countries are not available in the IMF's IFS, we tried to obtain rough estimates for these countries by using Bermuda's official statistics (the only country among the three for which data are available in World Bank and other sources), and by applying the overall average of the high-income group's development indicators. However, because of the volatile estimates derived, we decided to exclude these countries from our analysis in Section V.

${ }^{32}$ These include enforcement, rule of raw, regulation, burcaucracy, and property rights, and are taken from LLSV(1998). 
Table 1. Data Structure and Sources

\begin{tabular}{|c|c|c|c|c|}
\hline \multicolumn{2}{|c|}{ Variable } & Definition & Calculation & Sources \\
\hline \multicolumn{2}{|c|}{$Q$} & Output & $\begin{array}{l}\text { Total loans }+ \\
\text { Other earning assets }\end{array}$ & \multirow{8}{*}{$\begin{array}{l}\text { BankScope } \\
\quad+ \\
\text { Bank's annual } \\
\text { reports and } \\
\text { financial } \\
\text { statements } \\
\text { (if necessary) }\end{array}$} \\
\hline \multicolumn{2}{|c|}{$P$} & Price of output & Interest income /Output $(Q)$ & \\
\hline \multirow[t]{4}{*}{$w_{i}$} & $w_{l}$ & Price of labor & $\begin{array}{l}\text { Personnel expenses / } \\
\text { Number of employees }\left(x_{l}\right)\end{array}$ & \\
\hline & $w_{c}$ & Price of physical capital & $\begin{array}{l}\text { Other operating expense / } \\
\text { Fixed assets }\left(x_{c}\right)\end{array}$ & \\
\hline & $w_{d}$ & Price of deposits & $\begin{array}{l}\text { Interest expense / } \\
\text { Volume of deposits }\left(x_{d}\right)\end{array}$ & \\
\hline & $w_{k}$ & Price of financial capital & $\begin{array}{l}\text { Return on Average Equity or } \\
\text { alternative estimate of } \\
\text { opportunity cost }\end{array}$ & \\
\hline \multicolumn{2}{|c|}{$k$} & Financial capital & Equity capital & \\
\hline \multicolumn{2}{|c|}{$V C$} & Variable cost & $\begin{array}{l}\text { Personnel expenses }+ \\
\text { Interest expenses }+ \\
\text { Other operating expenses }\end{array}$ & \\
\hline \multirow[t]{5}{*}{$\phi_{i}$} & $\phi_{M}$ & Financial system size & $\begin{array}{l}\text { Domestic Credit + Demand } \\
\text { Deposits + Foreign assets }+ \\
\text { Foreign liabilities } \\
\text { ( } \phi_{M} / \text { GDP for financial depth) }\end{array}$ & $\begin{array}{l}\text { BDL (1999), } \\
\text { IFS }\end{array}$ \\
\hline & $\phi_{S}$ & Financial market size & $\begin{array}{l}\text { (Market capitalization/GDP) } \\
\times(\text { Total value traded/GDP }) \\
\times(\text { Turnover/GDP })\end{array}$ & $\begin{array}{l}\text { BDL } \\
\text { +Levine and } \\
\text { others }(2000)\end{array}$ \\
\hline & $\phi_{A}$ & Information transparency & Accounting standards & LLSV(1998) \\
\hline & $\phi_{N}$ & Asset quality & $\begin{array}{l}\text { Non-performing loans/Total } \\
\text { assets }\end{array}$ & \multirow[t]{2}{*}{ BankScope } \\
\hline & $\phi_{R}$ & Risk factor & Liquidity asset ratio & \\
\hline \multicolumn{2}{|c|}{ Others } & $\begin{array}{l}\text { Time trend variable }(t) \\
\text { Country dummy variables }\end{array}$ & $\begin{array}{c}t=1,2,3 \text { for } 1995-1997 \\
\text { dummy country }=1 \\
\text { otherwise } 0\end{array}$ & $\begin{array}{l}\text { WDI/GDF, } \\
\text { IFS }\end{array}$ \\
\hline
\end{tabular}


Table 2. Descriptive Statistics

\begin{tabular}{|c|c|c|c|c|}
\hline Variable & Descriptions & Average $^{11}$ & Min & $\operatorname{Max}$ \\
\hline \multicolumn{5}{|c|}{ Micro Banking Variables } \\
\hline$Q$ & Aggregate output ${ }^{2)}$ & 19.434 & 0.392 & 629.387 \\
\hline$x_{l}$ & Total number of employees & 4554.4 & 7.7 & 87933.3 \\
\hline$x_{d}$ & Total deposits ${ }^{2)}$ & 14.974 & 0.094 & 454.4 \\
\hline$x_{c}$ & Fixed assets ${ }^{2)}$ & 0.301 & 0.0001 & 7.2407 \\
\hline$K$ & Financial (equity) capital ${ }^{2 y}$ & 1.043 & 0.027 & 23.972 \\
\hline$R$ & Liquidity asset ratio (\%) & 24.36 & 0.0 & 667.69 \\
\hline $\begin{array}{l}q \\
(q a)\end{array}$ & $\begin{array}{l}\text { Non-performing loan ratio (\%) } \\
\text { (Adjusted NPL ratio) }\end{array}$ & $\begin{array}{r}4.04 \\
(6.62)\end{array}$ & $\begin{array}{r}0.0 \\
(0.0)\end{array}$ & $\begin{array}{r}81.81 \\
(149.01)\end{array}$ \\
\hline$P$ & Price of output ${ }^{3)}$ & 0.0798 & 0.0273 & 0.4411 \\
\hline$w_{l}$ & Price of labor ${ }^{3)}$ & 52.0867 & 1.8479 & 227.0494 \\
\hline$w_{d}$ & Price of deposits ${ }^{3)}$ & 0.0737 & 0.0072 & 5.752 \\
\hline$w_{c}$ & Price of physical capital ${ }^{3)}$ & 1.0123 & 0.0072 & 11.1472 \\
\hline$w_{k}$ & Price of financial capital (\%) & 10.7984 & -111.506 & 73.7343 \\
\hline \multirow[t]{2}{*}{$V C$} & Variable $\cos t^{2)}$ & 12.2815 & 0.0037 & 38.0422 \\
\hline & \multicolumn{4}{|c|}{ Macro Financial Variables } \\
\hline$M S$ & Financial market size & 36.5 & $\begin{array}{r}0.0 \\
\text { (Costa Rica) }\end{array}$ & $\begin{array}{r}1326.8 \\
\text { (Taiwan) }\end{array}$ \\
\hline \multirow[t]{2}{*}{$F S$} & Financial system size $\mathrm{e}^{2)}$ & 967.5 & $\begin{array}{r}2.4 \\
\text { (Bermuda) }\end{array}$ & $\begin{array}{c}20467.2 \\
\text { (Japan) }\end{array}$ \\
\hline & $\mathrm{M}^{2}{ }^{2)}$ & 233.7 & & $\begin{array}{r}5261.4 \\
\text { (U.S.) }\end{array}$ \\
\hline$A S$ & $\begin{array}{l}\text { Accounting standards } \\
\text { (information transparency) }\end{array}$ & 58.3 & $\begin{array}{r}24.0 \\
\text { (Bangladesh) }\end{array}$ & $\begin{array}{r}83.0 \\
\text { (Sweden) }\end{array}$ \\
\hline$C N$ & $\begin{array}{l}\text { Banking market concentration } \\
\text { ratio }\end{array}$ & 0.625 & $\begin{array}{l}0.186 \\
\text { (U.S.) } \\
\end{array}$ & $\begin{array}{r}1.0 \\
(5 \text { countries })^{4)}\end{array}$ \\
\hline Notes: & $\begin{array}{l}\text { All price-related figures are inflation-a } \\
\text { The means of micro banking variables } \\
\text { In US billion dollars. } \\
\text { In US thousand dollars. }\end{array}$ & sted and expr & d in US dollars. & \\
\hline
\end{tabular}




\section{ESTIMATION AND RESULTS}

\section{A. Existence of SSEs}

The parametric measures discussed in Section IV.C reveal the presence of significant scale economies associated with different indicators of financial system size (Table 3 ). Interestingly, SSEs are not detected by the conventional measures, ${ }^{33}$ while they turn out to be greater than one and increasing when the adjustment factors are incorporated in measurement (that is, as one moves from $\varepsilon_{V C Q}{ }^{\text {to }} \varepsilon_{T C Q}{ }^{\text {to }} \varepsilon_{V C Q}^{q}$ and to $\varepsilon_{T C Q}^{q}$ ).

This suggests that the SSEs in financial capitalization and risk management are relevant in bank production. In particular, Table 3 shows that scale economies change markedly in response to changes in the bank risk environment as proxied by the informationtransparency and asset-quality indicators: banks operating in highly transparent environment can expand production with a less than proportional increase in the cost of non-financial and financial resources needed to manage risks, as compared to banks operating in more opaque environments. Moreover, reputation signaling for banks with sound assets can be more efficient than for risky banks. For example, low-risk banks may be able to signal added levels of risk protection with less additional resources than high-risk banks, and can possibly save on risk-management costs, or even reduce their cost of funding, by signaling more financial strength.

Consistent with the importance of the factors relating to risk and information is the apparently counterintuitive finding that lower market concentration increases scale efficiency. ${ }^{34}$ Where competition is stronger (which is typically the case in larger and more developed financial systems), investor risk sensitivity is higher and signaling - as well as signal extraction - can be done more efficiently. As a result, scale economies associated with financial capitalization and risk management are larger than where competition is weaker, and banks do not need to invest as much in risk management and reputation signaling.

\footnotetext{
${ }^{33}$ In a broad sense, $\varepsilon_{T C Q}$ can be viewed as a sort of adjusted measure for $\varepsilon_{V C Q}$, but here it is regarded as a conventional measure in that no asset-quality adjustment was made. According to Table 3 , its mean values appeared to be very modest between small and large classes, ranging from 0.97 to 0.99 . The reason for small differential performances may be due to the use of shadow price of quasi-fixed input $\left(w^{*}{ }_{k}\right)$, rather than unobservable equilibrium price $\left(w_{k}\right)$.

${ }^{34}$ Since a dominant domestic bank operating in a highly concentrated market has a lower demand for financial capital (see Eq. (9)), a positive relationship should be expected to hold between market concentration and scale economies (as long as the marginal cost of financial capital, or the cost of signaling, is positive as in Hughes and Mester (1998)).
} 
Table 3. Scale Economies and Financial Variables

\begin{tabular}{|c|c|c|c|c|c|c|}
\hline \multirow{2}{*}{\multicolumn{3}{|c|}{ Financial variables ${ }^{2)}$}} & \multicolumn{2}{|c|}{$\begin{array}{c}\text { Conventional } \\
\text { Measure }^{1)}\end{array}$} & \multicolumn{2}{|c|}{$\begin{array}{l}\text { Quality-Adjusted } \\
\text { Measures }{ }^{1)}\end{array}$} \\
\hline & & & \multirow{2}{*}{$\begin{array}{r}\varepsilon V C Q \\
1.04\end{array}$} & \multirow{2}{*}{$\begin{array}{r}\varepsilon_{T C Q} \\
099\end{array}$} & \multirow{2}{*}{$\frac{\varepsilon_{V C Q}^{q}}{0.92}$} & \multirow{2}{*}{$\frac{\varepsilon_{T C Q}^{q}}{0.89}$} \\
\hline \multirow{5}{*}{$\begin{array}{l}\text { Financial } \\
\text { System Size } \\
(F S, M 2)\end{array}$} & \multirow{3}{*}{$F S$} & $\begin{array}{l}\text { Small } \\
(126)\end{array}$ & & & & \\
\hline & & $\begin{array}{l}\text { Medium } \\
(252)\end{array}$ & 0.93 & 0.97 & 0.98 & 1.02 \\
\hline & & $\begin{array}{l}\text { Large } \\
(2226)\end{array}$ & 0.87 & 0.98 & 104 & 1.18 \\
\hline & \multirow{2}{*}{$M 2$} & $\begin{array}{l}\text { Small }^{4)} \\
(105)\end{array}$ & 1.06 & 0.99 & 0.92 & 0.87 \\
\hline & & $\begin{array}{l}\text { Large } \\
(2505)\end{array}$ & 0.88 & 0.98 & 1.03 & 106 \\
\hline \multirow{2}{*}{$\begin{array}{l}\text { Financial } \\
\text { System Depth } \\
\left(F S D^{*} M S\right)\end{array}$} & \multicolumn{2}{|c|}{ Low (675) } & 0.95 & 0.98 & 0.98 & 1.02 \\
\hline & \multicolumn{2}{|c|}{ High (1950) } & 0.87 & 0.98 & 1.05 & 119 \\
\hline \multirow{2}{*}{$\begin{array}{l}\text { Financial } \\
\text { Market } \\
\text { Size }(M S)\end{array}$} & \multicolumn{2}{|c|}{ Small (1329) } & 0.92 & 098 & 1.01 & 1.09 \\
\hline & \multicolumn{2}{|c|}{ Large (1296) } & 0.85 & 0.97 & 1.05 & 121 \\
\hline \multirow{2}{*}{$\begin{array}{l}\text { Asset } \\
\text { Quality }\left(q_{a}\right)\end{array}$} & \multicolumn{2}{|c|}{ Low (879) } & 0.84 & 0.97 & 1.05 & 1.22 \\
\hline & \multicolumn{2}{|c|}{ High (1746) } & 0.91 & 0.98 & 1.02 & 1.11 \\
\hline \multirow{2}{*}{$\begin{array}{l}\text { Information } \\
\text { Transparency } \\
(A S)\end{array}$} & \multicolumn{2}{|c|}{ Low (330) } & 0.98 & 098 & 0.95 & 0.96 \\
\hline & \multicolumn{2}{|c|}{ High (2295) } & 0.87 & 0.98 & 104 & 117 \\
\hline \multirow{2}{*}{$\begin{array}{l}\text { Market } \\
\text { Concentration } \\
(C N)\end{array}$} & \multicolumn{2}{|c|}{$\operatorname{Low}^{5)}(2016)$} & 0.87 & 0.98 & 1.04 & 118 \\
\hline & \multicolumn{2}{|c|}{ High (609) } & 0.95 & 103 & 0.98 & 1.03 \\
\hline
\end{tabular}

Notes: 1) The shaded area represents higher scale economies for each classification of financial variables.

2) The figures in parenthesis represent the number of obscrvations.

$3)$ In billion of US dollars.

4) $M 2<10$.

5) Less than 0.5 .

6) All the parametric estimates reported above are statistically different at the $5 \%$ significance level. Differences refer to comparisons of: conventional vs. adjusted measures; small $v s$. large classes; and low vs. high classes. 
This evidence in support of SSEs is confirmed by regressing the economic-cost and quality-adjusted measure of scale economies $\left(\varepsilon_{T C Q}^{q}\right)$ on different size indicators of financial system and markets, and on a number of variables reflecting bank market-structure, riskenvironment, and institutional characteristics. Following the model specification applied by Demirgüç-Kunt and Huizinga (1999), Claessens, Demirgüç-Kunt and Huizinga (2001), and Claessens and Lee (2002), ${ }^{35}$ panel estimation was carried out using both country and banking observations (Table 4).

Table 4. Determinants of SSEs

\begin{tabular}{ccccc}
\hline & \multicolumn{3}{c}{ Country observations } & Banking observations \\
\hline Dependent variable: & $\begin{array}{c}\text { (1) Total } \\
\text { estimates }\end{array}$ & $\begin{array}{c}\text { (2) Between } \\
\text { estimates }\end{array}$ & $\begin{array}{c}\text { (3) Random effects } \\
\text { estimates }\end{array}$ & $\begin{array}{c}\text { (4) Random effects } \\
\text { estimates }\end{array}$ \\
$\begin{array}{c}q \\
T C Q\end{array}$ & & & & \\
Independent variables: & & & & \\
Financial System Size & $0.0225^{* * *}$ & $0.0227^{* * *}$ & $0.0229^{* * *}$ & $0.0230^{* * *}$ \\
$(F S)_{\mathrm{jt}}$ & $(7.718)$ & $(2.289)$ & $(5.957)$ & $(15.999)$ \\
Financial System Depth & $0.0259^{* * *}$ & $0.0257^{* * *}$ & $0.0242^{* * *}$ & $0.0173^{* * *}$ \\
$(F S D)_{\mathrm{jt}}$ & $(6.853)$ & $(3.909)$ & $(4.309)$ & $(7.442)$ \\
Financial Market Size & $0.0164^{* * *}$ & $0.0160^{* * *}$ & $0.0174^{* * *}$ & $0.0131^{* * *}$ \\
$(M S)_{\mathrm{jt}}$ & $(13.159)$ & $(6.883)$ & $(17.873)$ & $(24.817)$ \\
Institutions & $0.0327^{* * *}$ & $0.0335^{* *}$ & $0.0264^{* *}$ & $0.0170^{* * *}$ \\
$(I N S)_{\mathrm{jt}}$ & $(3.971)$ & $(2.354)$ & $(2.183)$ & $(2.725)$ \\
Market Concentration & $-0.0210^{* *}$ & -0.0218 & -0.0163 & $-0.0118^{* * *}$ \\
$(C N)_{\mathrm{jt}}$ & $(1.752)$ & $(1.003)$ & $(1.475)$ & $(3.574)$ \\
Asset Quality (adjusted & & & & $-0.0118^{* * *}$ \\
for Accounting & -0.0046 & -0.0043 & $-0.0074^{*}$ & $(22.412)$ \\
Standards) & $(1.824)$ & $(0.718)$ & $(1.807)$ & $-0.3637^{* * *}$ \\
$(q / A S)_{\mathrm{jjt}}$ & & & \\
Constant & $-0.4470^{* * *}$ & $-0.4512^{* * *}$ & $-0.4247^{* * *}$ & $(23.760)$ \\
\hline Adjusted $R^{2}$ & $(17.257)$ & $(9.844)$ & $(12.212)$ & 0.746 \\
No. of observations & 0.881 & 0.881 & 0.880 & 2625 \\
\hline
\end{tabular}

Notes: 1) Regressions are estimated using panel estimation on pooled bank level data $(i)$ across 75 countries $(j)$ for 1995-1997 $(t)$. Here, Total estimates are obtained by from OLS while Between estimates are from OLS on mean values. Within (fixed effect) estimates are not available because some parameter cannot be estimated due to singularity of data (i.e., some macro financial variables already reflected countryspecific differences). The Random effects model (which is our preferred model specification) produces variance component estimates.

2) The dependent variable is the adjusted scale measure of $\varepsilon_{T C Q}^{q}$. All are $\log$ variables.

3) The figures in parenthesis beneath the parameter estimates are $t$-statistics.

4) Superscripts ${ }^{* * *}$, and ${ }^{* *}$ indicate significance levels of 10,5 , and 1 percent, respectively.

35 The basic model specification is $I_{i j t}=\alpha_{o}+\beta_{i} B_{i j t}+\beta_{j} X_{j t}+\varepsilon_{i j t}$, where $I_{i j t}$ is the dependent variable for domestic bank $i$ in country $j$ at time $t ; B_{i j t}$ are bank-specific financial variables for domestic bank $i$ in country $j$ at time $t$; and $X_{j t}$ are country-specific variables for country $j$ at time $t$. Here, $\alpha_{o}$ is a constant, and $\beta_{i}$ and $\beta_{j}$ are coefficients while $\varepsilon_{i j t}$ is an error term. 
The results indicate that financial system size, risk environment, institutional development, and market concentration have considerable explanatory power on scale efficiency. The panel regression results show that parameter estimates, with only a few exceptions, are statistically significant at the $1 \%$ level and that all have a correct sign. In fact, statistical significance is complete under our preferred model specification using banking observations (column 4).

These results confirm that larger size and better institutions generate higher scale efficiency. Similarly, and as expected, more competitive banking markets, higher asset quality (i.e., a lower $q$ ), and more information transparency $(A S)$ result in higher scale efficiency levels. These relationships are graphically presented in Figures 1-5 below.

The results also raise issues relating to the relationship between banks and financial markets, discussed in Box 1 below.

Figure 1. Relationship Between Scale Economies and Financial System Size

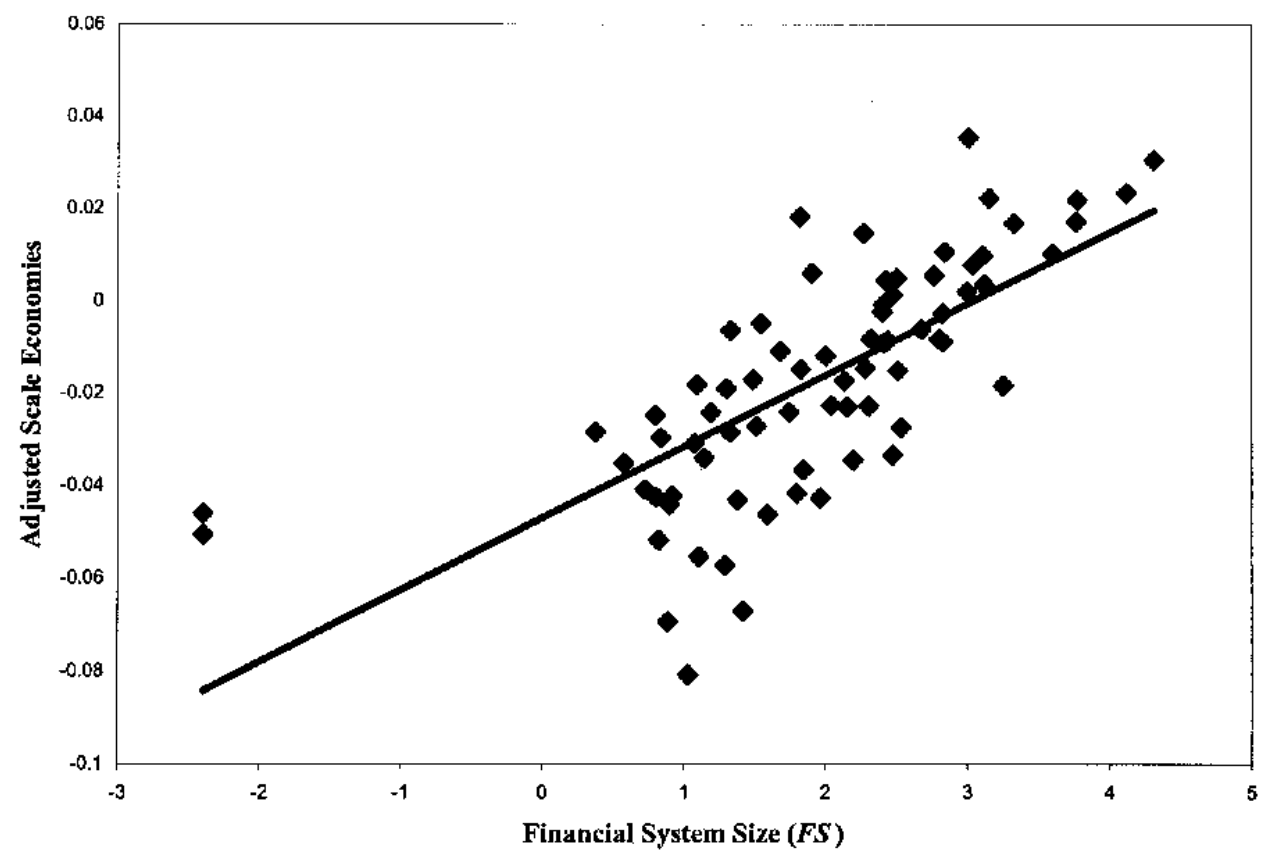

Note: The relationship between $\mathrm{X}$ and $\mathrm{Y}$ is expressed in log-linear form 
Figure 2. Relationship Between Scale Economies and Financial Market Size

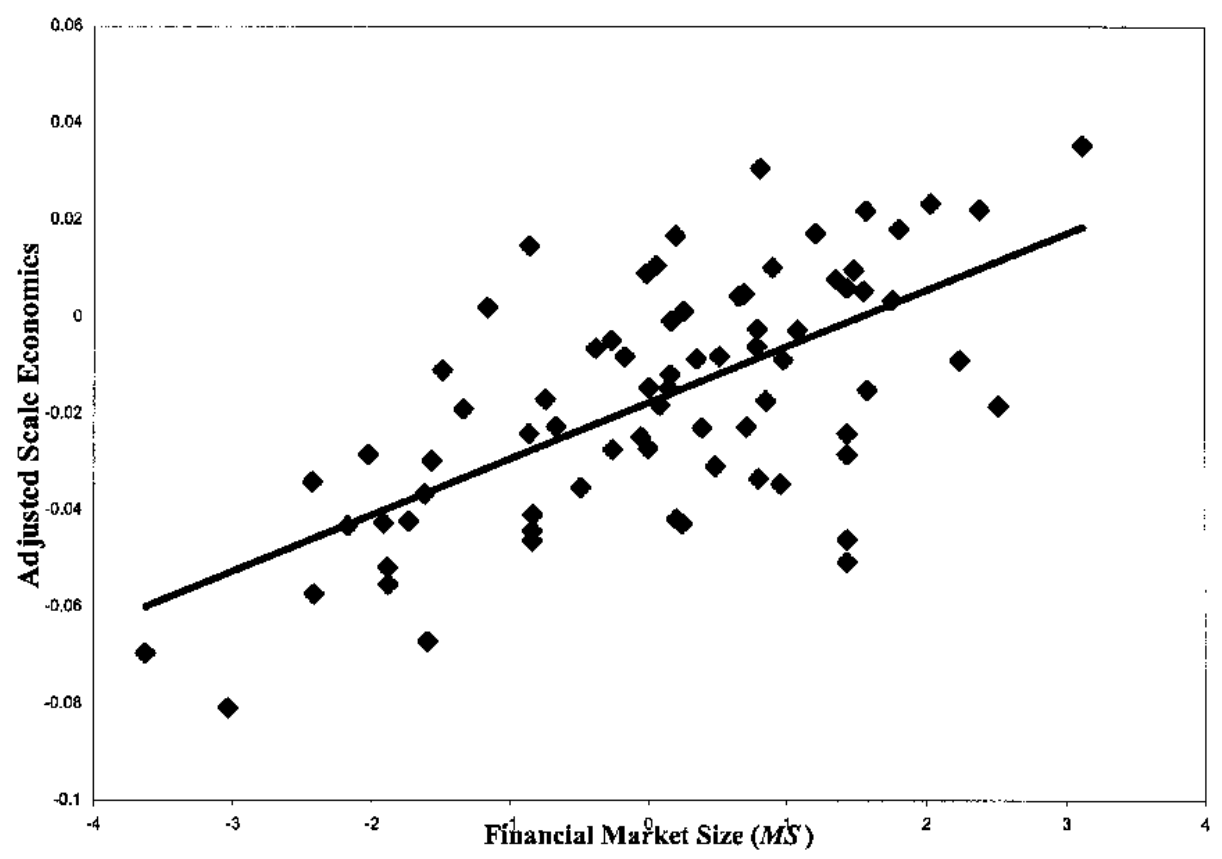

Note: The relationship between $\mathrm{X}$ and $\mathrm{Y}$ is expressed in log-linear form

Figure 3. Relationship Between Scale Economies and Institutional Development

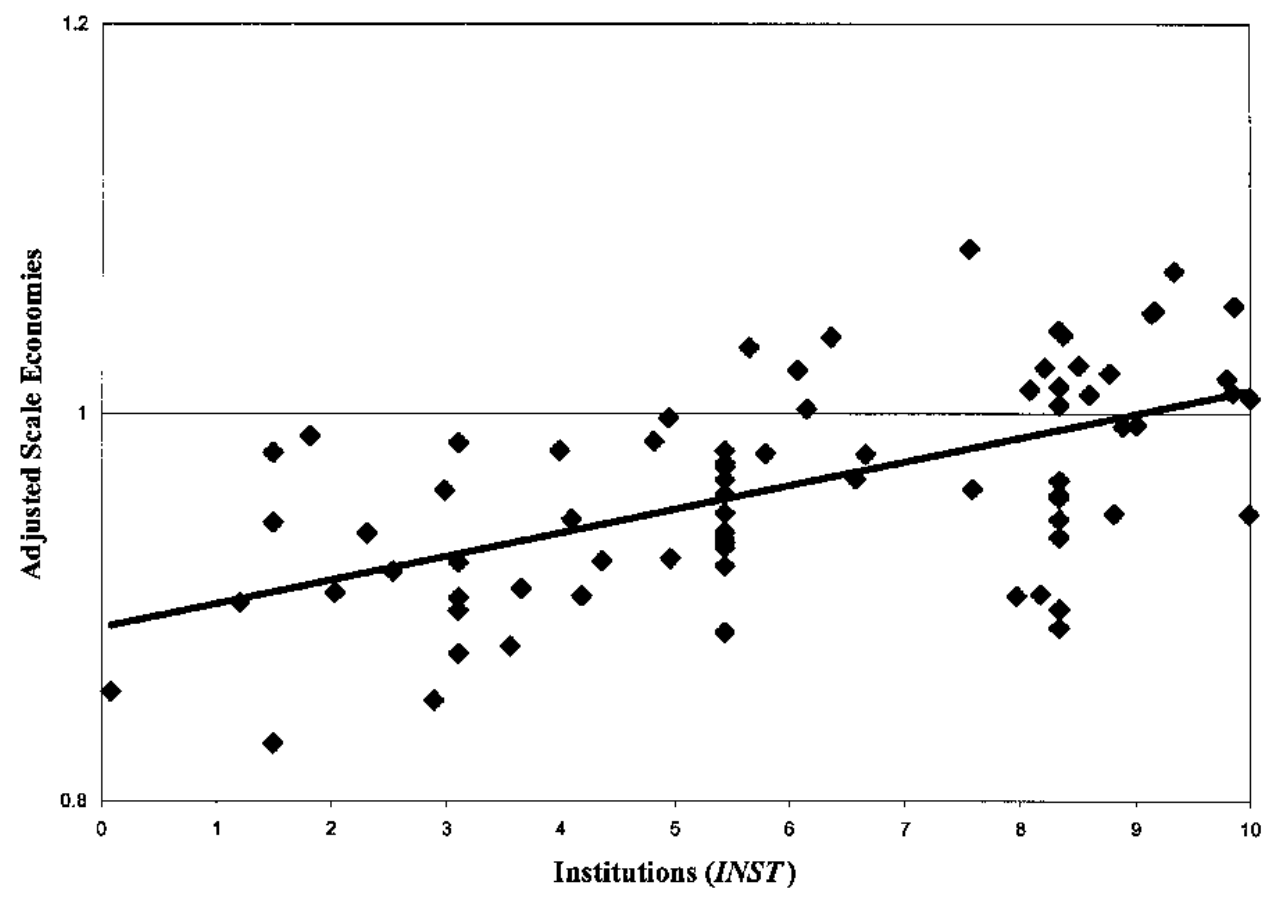


Figure 4. Relationship Between Scale Economies and Market Concentration

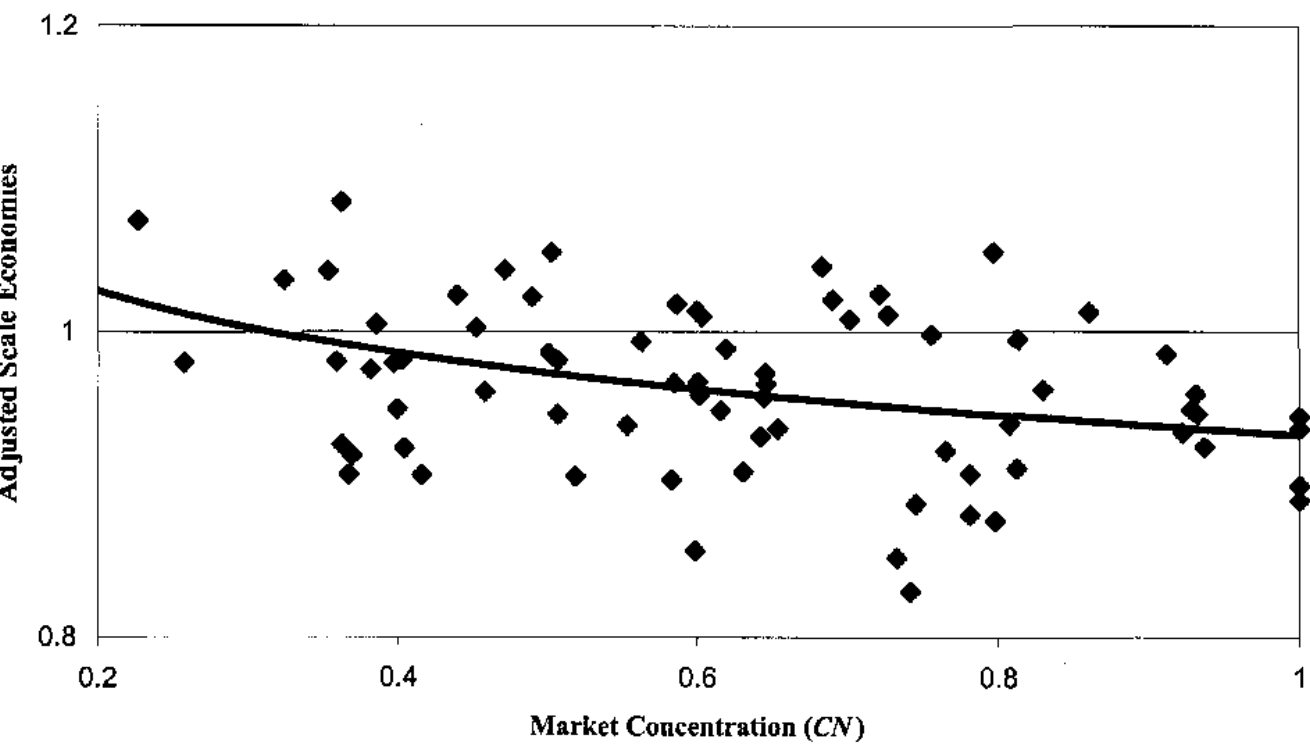

Figure 5. Relationship Between Scale Economies and Non-Performing Loans

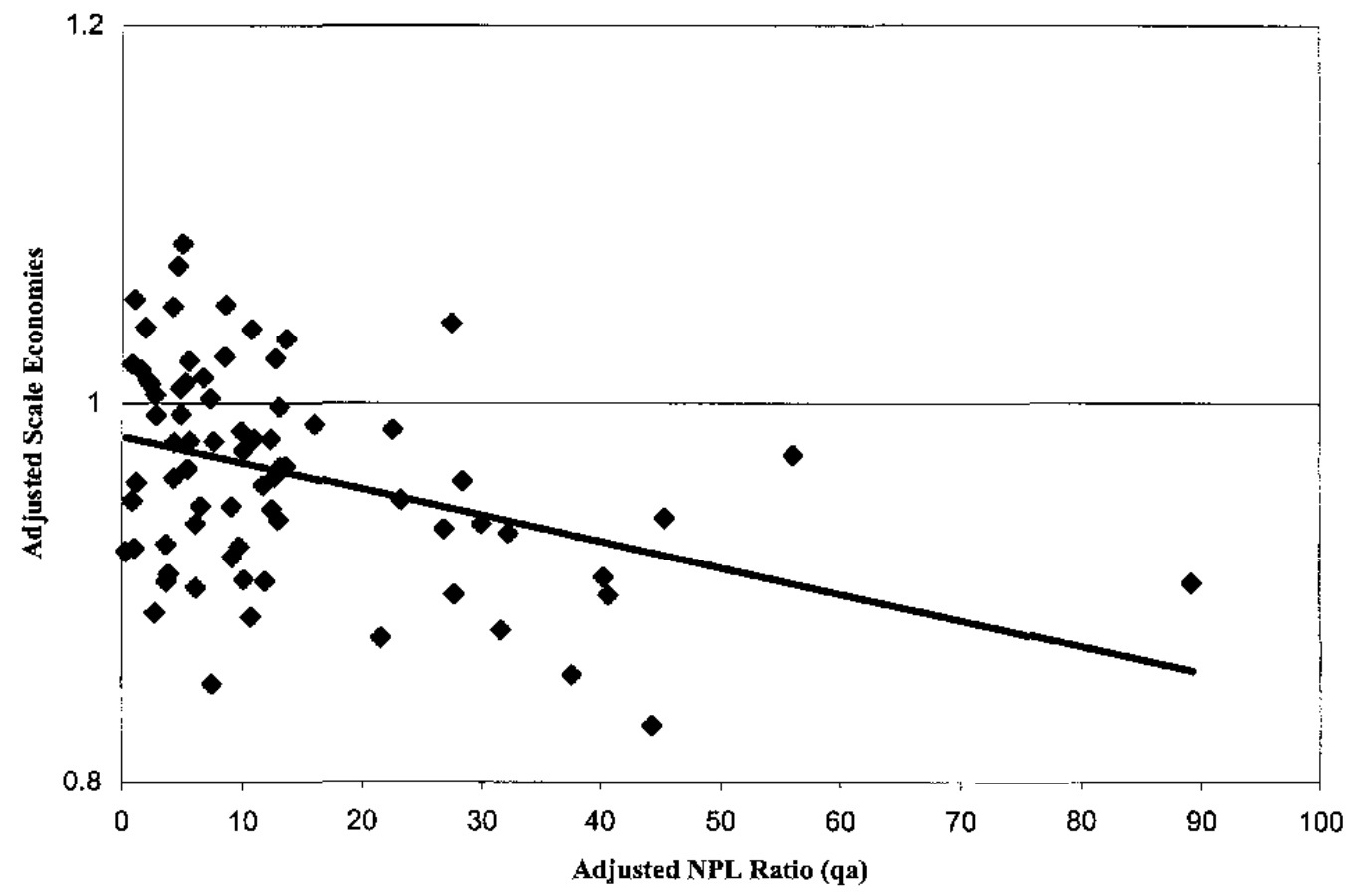




\section{Box 1. Banks and Financial Markets: Supplements or Complements?}

Consistent with recent findings, ${ }^{36}$ the results reported in Table 4 support the existence of complementarities between banks and financial market institutions. However, unlike previous studies and evidence, and in line with the SSE hypothesis formulated in this study, the results point to complementarities running from markets to banks. They show how bank efficiency can gain from developed financial markets, in the face of the prediction from well-known studies that developed financial markets ultimately cause the banking sector to shrink. ${ }^{37}$

In fact, our results do not necessarily contradict that prediction. One may notice that the informational externalities springing from efficient financial markets strengthen the competitiveness of those banks that are best equipped to benefit from better information use. In this case, only such banks would be able to survive in an otherwise shrinking traditional banking business sector, while others would go out of the market. Furthermore, the presence of efficient financial markets allows banks to improve their riskmanagement capacity and, hence, their potential to expand their business into nonbanking financial areas, where demand for cross-sectional risk-sharing services is high and growing vis-à-vis the consolidating market of deposit and loan contracts. ${ }^{38}$ Accordingly, the development of financial markets would dynamically induce banking to shift from activities that stand to lose competition with financial market services to those that exploit complementarities with the financial markets.

It must be noted, however, that while traditional banking activities tend to consolidate, they retain key functions - such as money creation (Bossone 2001 a, 2001b) and contingent liquidity provision to nonbank financial institutions (Corrigan 1982, 2000) - that are essential to the functioning and development of financial markets. These functions not only underpin fundamental complementarities running from banks to markets, but point to the fact that the traditional banking business cannot be compressed beyond certain limits.

${ }^{36}$ Demirgüç-Kunt and Levine $(1996,2001)$ and Levine (2000) find evidence of strong complementarities between bank and capital-market financing in affecting economic growth. Evidence showing that banks supply capital markets with valuable information is reported by James (1987), Slovin, Sushka and Hudson (1988), Lummer and McConnell (1989), and Biller, Flannery and Garfinkel (1995).

${ }^{37}$ See for instance Jacklin (1987), Jacklin and Bhattacharya (1988), Diamond (1997), and Allen and Gale $(1999,2001)$.

${ }^{38}$ For the expansion of banks into the business of cross-sectional risk-sharing business, and their disintermediation from traditional activities, see Allen and Santomero (2001). 
The relevance of the risk-environment variables is consistent with the findings in Table 3 above. This leads to the presumption that SSEs are a product of the relationship between financial system size and the quality of the risk environment for banking intermediation: a larger, deeper, and more efficient system helps banks to save on the resources needed to manage the higher risks associated with larger production. The evidence below seems to support such a presumption.

The positive relationship between financial system size and scale efficiency in financial capitalization and risk management is illustrated quite clearly by Tables 5-6, which report the values of $\varepsilon_{V C Q}$ and $\varepsilon q C Q$ estimated for subgroups of banks by bank scale and financial system size. Whereas conventional measures indicate the existence of modest scale economies only for small banks in small systems, adjusted measures show economies of scale to increase with both bank scale and system size.

Table 5. Conventional Scale Economies $(\varepsilon V C Q)$ by Size of Banks and Financial Systems

\begin{tabular}{|c|c|c|c|c|}
\hline $\begin{array}{l}\text { Financial } \\
\text { Banktem } \\
(\text { ta: } \text { total asset })\end{array}$ & $\begin{array}{c}\text { Small } \\
(F S<35)\end{array}$ & $\begin{array}{c}\text { Medium } \\
(35<F S<300)\end{array}$ & $\begin{array}{c}\text { Large } \\
(300<F S)\end{array}$ & Total ${ }^{3)}$ \\
\hline $\begin{array}{c}\text { Small } \\
(t a<2.4)\end{array}$ & $\begin{array}{l}1.05 \\
(96)\end{array}$ & $\begin{array}{l}0.94 \\
(84)\end{array}$ & $\begin{array}{c}0.86 \\
(690)\end{array}$ & $\begin{array}{c}0.90 \\
(876)\end{array}$ \\
\hline $\begin{array}{c}\text { Medium } \\
(2.4<t a<8.0)\end{array}$ & $\begin{array}{l}1.05 \\
(24)\end{array}$ & $\begin{array}{c}0.92 \\
(102)\end{array}$ & $\begin{array}{c}0.87 \\
(738)\end{array}$ & $\begin{array}{c}0.89 \\
(876)\end{array}$ \\
\hline $\begin{array}{c}\text { Large } \\
(t a>8.0)\end{array}$ & $\begin{array}{c}0.97 \\
(6)\end{array}$ & $\begin{array}{l}0.94 \\
(66)\end{array}$ & $\begin{array}{c}0.87 \\
(798)\end{array}$ & $\begin{array}{c}0.88 \\
(873)\end{array}$ \\
\hline Total & $\begin{array}{c}1.04 \\
(126)\end{array}$ & $\begin{array}{c}0.93 \\
(252)\end{array}$ & $\begin{array}{c}0.87 \\
(2226)\end{array}$ & $\begin{array}{c}0.89 \\
(2625)\end{array}$ \\
\hline
\end{tabular}

Notes: 1) The figures in parentheses are the numbers of sample bank observations. All are 1995-97 mean values for each subgroup.

2) In billion US dollar.

3) Another fourth subgroup of three countries (21 total observations) was included in the calculation of the total average in the following tables, unless otherwise specified.

Two interesting observations from Table 6 are that small banks in large systems are considerably more cost efficient than small banks in small systems (1.06 and 0.93 , respectively) and that, on the whole, bank scale does not make much of a difference within classes of financial system size. 
Table 6. Adjusted Scale Economies $\left(\varepsilon_{V C Q}^{q}\right)$ by Size of Banks and Financial Systems

\begin{tabular}{|c|c|c|c|c|}
\hline $\begin{array}{c}\text { Financial } \\
\text { System } \\
\text { Size }(F S)\end{array}$ & Small & Medium & Large & Total \\
& & & & \\
\hline Bank Size $(t a)$ & & & & \\
\hline \multirow{2}{*}{ Small } & 0.93 & 0.99 & 1.06 & 1.04 \\
& $(96)$ & $(84)$ & $(690)$ & $(876)$ \\
\hline Medium & 0.91 & 0.98 & 1.05 & 1.03 \\
& $(24)$ & $(102)$ & $(738)$ & $(876)$ \\
\hline Large & 0.95 & 0.96 & 1.02 & 1.01 \\
& $(6)$ & $(66)$ & $(798)$ & $(873)$ \\
\hline \multirow{2}{*}{ Total } & 0.93 & 0.98 & 1.04 & 1.03 \\
& $(126)$ & $(252)$ & $(2226)$ & $(2625)$ \\
\hline
\end{tabular}

Notes: 1) The figures in parentheses are the numbers of sample bank observations.

2) All are 1995-97 mean values for each subgroup.

Additional evidence in support of SSEs in production and risk management can be found by analyzing bank cost structures. From production theory, the elasticity of variable cost to output can be expressed as the ratio of marginal cost to average cost. ${ }^{39}$ Using a hypothetical total cost function that incorporates the shadow cost of financial capital, $C_{T}=$ $C_{V}+\left(-\partial C_{V} / \partial k\right) k{ }^{40}$ we estimated the average-cost/marginal-cost ratio for each subgroup of banks by bank scale and financial system size (Table 7). ${ }^{41}$ Note that ratio values larger (smaller) than 1 imply economies (diseconomies) of scale. It can be observed that both average and marginal costs decrease as the size of the banks and the financial system increases. Also, scale economies increase with the size of the financial system.

${ }^{39}\left(\varepsilon_{C Q}\right)^{-1}=\partial \ln C / \partial \ln Q=(\partial C / \partial Q)(Q / C)=M C / A C$

${ }^{40}$ The reason for using a shadow total cost function here is that it is difficult to obtain a quality-adjusted $A C$ and $M C$ directly with the underlying variable cost function. Note that the indirect measure of scale economies, derived from the ratio of $A C / M C$ in the bottom line of Table 7 will be slightly different from that of other direct measures, due to rounding and aggregations errors of computation.

${ }^{41}$ Parametric estimates of the marginal total $\operatorname{cost}\left(\partial C_{T} / \partial Q\right)$ are directly obtained by differentiating the shadow total cost function with respect to $Q$. 
Table 7. Average and Marginal Total Cost by Size of Banks and Financial Systems

\begin{tabular}{|c|c|c|c|c|}
\hline $\begin{array}{c}\text { Financial } \\
\text { System } \\
\text { Size }(F S)\end{array}$ & Small & Medium & Large & Total \\
& & & & \\
\hline Bank Size $(t a)$ & & & & \\
\hline Small & 0.094 & 0.120 & 0.083 & 0.087 \\
& $(0.093)$ & $(0.110)$ & $(0.075)$ & $(0.080)$ \\
\hline Medium & 0.120 & 0.082 & 0.079 & 0.079 \\
& $(0.120)$ & $(0.078)$ & $(0.073)$ & $(0.074)$ \\
\hline Large & 0.071 & 0.073 & 0.068 & 0.068 \\
& $(0.068)$ & $(0.070)$ & $(0.065)$ & $(0.066)$ \\
\hline Tota ${ }^{3)}$ & 0.098 & 0.091 & 0.076 & 0.078 \\
& $(0.095)$ & $(0.086)$ & $(0.071)$ & $(0.073)$ \\
\hline$\left.\varepsilon^{*}{ }_{T C Q}=A C / M C\right]$ & {$[1.03]$} & {$[1.06]$} & {$[1.08]$} & {$[1.06]$} \\
\hline
\end{tabular}

Notes: 1) Marginal costs are reported in parentheses.

2) All are 1995-97 mean values for each subgroup.

3) 15 outlier observations for $M C$ (negative or close to 0 ) are excluded in the calculation of average in the case of small and medium financial system.

\section{B. SSEs in Production and Risk Management}

With robust signs supporting the existence of SSEs, it is now interesting to try to determine the quantitative relevance of the individual SSE channels discussed in Section III. A good starting point is the decomposition of the adjusted scale economies measure (Table 8). The following features emerge from such decomposition. First, financial system size affects negatively bank production costs (component $A$ ), perhaps as a result of the disproportionate variations in labor costs observed across financial system sizes. ${ }^{42}$

Second, banks in large systems more than offset production diseconomies through cost savings generated by financial capitalization (in other words, additional capital reduces variable costs), whereas this option is not available to banks in small systems (component $B$ ).

Third, changes in bank risk level generate larger cost increases in large systems than in small ones (component $C$ ). This is consistent with the findings discussed above concerning the relevance of the bank risk-environment factors: in larger systems, with more efficient information provision and more signal-extraction capacity, investors are more reactive to changes in risks, value-maximizing banks allocate more resources to managing risks, and the banks' cost of funding is more sensitive to changes in risk perceptions.

${ }^{42}$ Reductions in the quantity of labor inputs due to scale cconomies can be more than offset by the increase in the cost of labor inputs. 
Fourth, in larger systems banks can offset such diseconomies by adding more capital (component $D$ ), suggesting that where information is provided and used more efficiently, signaling more financial strength allows banks to save on risk-management costs and possibly reduce their cost of funding. Once again, this option is not available to banks in small systems.

Table 8. Decomposition of Adjusted Scale Economies by Financial System Size

\begin{tabular}{|c|c|c|c|c|c|}
\hline Sources & $\frac{\partial \ln C_{V}}{\partial \ln Q}$ & $\frac{\partial \ln C_{V}}{\partial \ln k} \frac{\partial \ln k}{\partial \ln Q}$ & $\frac{\partial \ln C_{V}}{\partial \ln q}$ & $\frac{\partial \ln C_{V}}{\partial \ln k} \frac{\partial \ln k}{\partial \ln q}$ & $\frac{\varepsilon_{V C Q}^{q}}{(D)}$ \\
$\begin{array}{l}\text { Financial } \\
\text { System Size } \\
(F S)\end{array}$ & 0.9577 & 0.0932 & 0.0038 & 0.0218 & \begin{tabular}{c}
$\frac{1}{(A+B+C+D)}$ \\
\hline Small
\end{tabular} \\
\hline Medium & 1.0718 & -0.0712 & 0.0403 & -0.0214 & 0.9776 \\
\hline Large & 1.1502 & -0.1904 & 0.0564 & -0.0585 & 1.0415 \\
\hline
\end{tabular}

Notes: 1) All are mean values during 1995-97 for each subgroup.

2) $\varepsilon q C Q$ will not be exactly same as $1 /(A+B+C+D)$, due to averaging and rounding errors.

As discussed under Proposition 1, another source of evidence of SSEs is the presence of dynamic efficiency effects of financial system size on bank costs, due to changes in technology. We estimated such effects indirectly by including the time trend term $(t)$ in our model specification, as a proxy for technical progress, and by measuring the impact of technical change on bank variable cost controlling for financial system size. We derived parametric estimates of technical change over the variable cost function estimated for each class of financial system size. Differentiating the variable cost function with respect to $t$ and taking it with the negative sign yield a measure of technical progress

$$
\varepsilon_{V C t}=-\frac{\partial \ln C_{V}}{\partial t}=-\left(\alpha_{t}+\sum_{i} \beta_{i t} \ln Z_{i}\right)
$$

where $\varepsilon_{V C t}>0$ implies a cost saving over time.

Table 9 compares the estimates of $\varepsilon_{V C t}$ reported as yearly rates of variable cost variation. Only banks operating in large financial systems show a decreasing rate of variable cost $(0.07 \%$ annually). On the other hand, banks in medium-sized systems show an annual rate of increment $(0.09 \%)$, and those in small systems have a much higher rate of cost increment $(2.7 \%)$. Note that the estimated cost function includes country-specific differences, so that the estimated technology-related SSE effects are not affected by the different levels of country economic development. 
Observing the parameter estimates for $\beta_{i t}$ in Eq. (14), ${ }^{43}$ it can be noticed that the sign of the coefficient for deposits $(d)$ and physical capital $(c)$ and for the scale-related variables of output $(Q)$, financial system $(F S)$ and market size $(M S)$ is negative. This implies that a larger bank operating at a large scale of deposits and loans within a large and deep financial system is expected to show quite a large cost saving over time. Table 9 confirms that the overall rate of cost saving is highest in the large banks in large systems. On the other hand, the estimates for $\varepsilon_{v C l}$ in the small and medium systems are negative, indicating weak scale effects.

The derived estimates can be interpreted as the rates of change in cost, over the sample period considered, made possible by technology development through the interaction of network externalities and scale economies. The findings support the hypothesis that the size of the financial system matters, and suggest that small banks operating in large financial systems are financially more viable than small banks operating in small systems.

Table 9. SSEs and Technological Change

\begin{tabular}{|c|c|c|c|c|}
\hline $\begin{array}{c}\text { Financial } \\
\text { System } \\
\text { Size }(F S)\end{array}$ & Small & Medium & Large & Total \\
\hline Bank Size $(t a)$ & & & & \\
\hline Small & -0.0270 & -0.0130 & 0.0006 & -0.0001 \\
\hline Medium & -0.0220 & -0.0008 & 0.0005 & 0.0002 \\
\hline Large & -0.0300 & -0.0005 & 0.0009 & 0.0008 \\
\hline Total & -0.0270 & -0.0009 & 0.0007 & 0.0003 \\
\hline
\end{tabular}

Notes: 1) The figures represent rates of technical progress. Positive (negative) values indicate annual rates of cost diminution (increment) during the sample period.

2) All are 1995-97 mean values for each subgroup.

Proposition 2 predicts that SSEs are associated with large, deep, and efficient financial markets. Access to larger markets reduces bank costs by providing banks with more efficient instruments of risk management and reputation signaling enabling them to economize on the financial capital required by higher production. This prediction is supported by the estimated parameters of the endogenous demand equation for financial

43 Maximum likelihood estimation results yield $\varepsilon_{V C}=-\left(0.0355+0.0117 \ln w_{l}-0.0092 \ln w_{d}-0.0025 \ln w_{c}+\right.$ $0.0013 \ln k+0.0009 \ln q a-0.0048 \ln Q-0.0065 \ln F S-0.0002 \ln M S+0.0234 t$ ). 
capital (Eq. (9)), which shows that the demand for financial capital increases with output and non-performing loans, while it decreases with the size of the capital markets (Table 10).

Since each parameter of Eq. (9) represents an elasticity coefficient of the demand for capital, we were able to gauge how much additional financial capital is required with respect to changes in each of the arguments of the financial capital demand function. We defined the total elasticity of financial capital $\left(\varepsilon_{k}\right)$ for each class of financial system size, averaged over country $(j)$ and under constant macro financial factors, as

$$
\begin{aligned}
\varepsilon_{k}^{S} & =\frac{1}{n}\left(\sum_{j \in S}^{n} \frac{\partial \ln k}{\partial \ln Q_{j}}\right)+\left[\frac{\partial \ln k}{\partial \ln F S}+\frac{\partial \ln k}{\partial \ln M S}+\frac{\partial \ln k}{\partial \ln q}+\frac{\partial \ln k}{\partial \ln C N}\right] \\
& =\widetilde{\varepsilon}_{k Q}^{s}+\left[\varepsilon_{k F S}+\varepsilon_{k M S}+\varepsilon_{k q}+\varepsilon_{k C N}\right]
\end{aligned}
$$

where the elasticity of financial capital with respect to output is broken down by financial system size, as indicated by the super-script $s$ (indicating small, medium, and large system size). Elasticity $\varepsilon_{k}^{s}$ measures the total economies in capitalization in each subgroup of banks in the different classes of financial system size. ${ }^{44}$ According to the results reported in Table 10 , the overall sum of the partial elasticities $\left(\varepsilon_{k}^{S}\right)$ is the highest for banks in small systems (1.280). ${ }^{45}$

The results show that, as output increases, banks operating in medium and large financial systems require a less than proportionate increase in financial capital than those operating in small systems. This implies that, as the financial system becomes larger and deeper, banks need relatively less financial capital to manage risks and to signal their strength to the market as they expand production. Note, in line with Proposition 2, the significant SSE effect of financial market depth and efficiency $(M S)$ once the absolute size of the financial system $(F S)$ is controlled for. This suggests that, for any given size of the financial system, more efficient market infrastructures allow banks to use financial capital more efficiently (all else being equal).

\footnotetext{
${ }^{44}$ This coefficient is equivalent to Hughes' and Mester's (1998) measure of economies capitalization (ELSTK), whose reported value was 0.7153 with asset quality adjustment for the US banking system.

${ }^{45}$ Unexpectedly, $\varepsilon_{k}^{S}$ is lower in medium-size systems $(0.787)$ than in the large systems (0.999), although the estimate for medium systems is not statistically as significant as the one for large systems. The lower level of economies of capitalization in medium systems might be due to some outliers in the medium system countries' parameter estimates $\left(\varepsilon_{k Q}^{j \in S}\right)$ showing an unrealistic negative sign.
} 
Table 10. Economies of Capitalization and Financial System Size

\begin{tabular}{lcccccc}
\hline $\begin{array}{l}\text { Financial } \\
\text { System } \\
\text { Size }(F S)\end{array}$ & $\begin{array}{c}\widetilde{\varepsilon}_{k Q}^{s} \\
(1)\end{array}$ & $\begin{array}{c}\varepsilon_{k F S} \\
(2.1)\end{array}$ & $\begin{array}{c}\varepsilon_{k M S} \\
(2.2)\end{array}$ & $\begin{array}{c}\varepsilon_{k q} \\
(2.3)\end{array}$ & $\begin{array}{c}\varepsilon_{k C N} \\
(2.4)\end{array}$ & $\begin{array}{c}\varepsilon_{k}^{S} \\
(1)+(2)\end{array}$ \\
\hline \multirow{2}{*}{ Small } & $1.845^{* * *}$ & & & & & $1.280^{* * *}$ \\
& $(10.55)$ & & & & & $(2.71)$ \\
Medium & $1.352^{* * *}$ & 0.203 & $-0.197^{* * *}$ & $0.456^{* * *}$ & $-0.938^{* * *}$ & $0.787^{*}$ \\
& $(14.03)$ & $(0.91)$ & $(3.02)$ & $(7.66)$ & $(3.04)$ & $(1.83)$ \\
Large & $1.519^{* * *}$ & & & & & $0.954^{* *}$ \\
& $(19.82)$ & & & & & $(2.33)$ \\
Total & $1.565^{* * *}$ & & & & & $0.999^{*}$ \\
& $(16.91)$ & & & & & $(2.32)$
\end{tabular}

Notes: 1) The figures in parentheses beneath the estimates are $t$-statistics.

2) *,*, *** indicates significance levels of 10,5 , and $1 \%$, respectively.

3) $\widetilde{\varepsilon}_{k Q}^{s}$ is the average of parameter estimates within the same class of system size countrics.

Note also that the banks' need for additional financial capital declines with the concentration of the banking market. This may be due to the fact that a less competitive market environment present banks with lower risks, and allows them to economize on the use of additional financial capital as a signaling device when they expand production. ${ }^{46}$

The existence of SSEs in financial capitalization can be detected also by observing the degree of utilization of financial capital by banks across different classes of financial system size. As assumed in Proposition 2, banks in small systems should systematically hold relatively larger stocks of financial capital than banks in large systems (all else being equal).

Before exploring the degree of financial capital utilization, we first need to get an equilibrium market rental price of capital $\left(w_{k}\right)$ that could be proxied easily. In general, the most practical proxy readily available is the return on average equity $(R O A E)$. Table 11 compares average ROAEs directly obtained from the BankScope database for each subgroup of different classes of bank scale and financial system size. The overall sample average $R O A E$ is $11 \% .{ }^{47}$ The ROAEs for the small and medium financial systems $(15 \%$ and $16 \%$, respectively) are considerably higher than that for large systems $(10 \%)$. Among the different classes of bank size in terms of assets, small banks yield the highest $R O A E(13 \%)$, followed by medium banks $(11 \%)$, and by large banks $(8 \%)$.

${ }^{46}$ This result (which refers to the responsiveness of financial capital to risk) is not inconsistent with the results found earlier, whereby a more competitive environment enables banks to use a given stock of financial capital more efficiently, owing to more efficient information provision and signal extraction.

${ }^{47}$ Hughes, Mester and Moon (2001) performed a check for over- or under- utilization of financial capital by assuming $w_{k}$ to be around $0.14 \sim 0.18$. 
However, since the $R O A E$ may not be suited for our assumed single-product cost function, we used an alternative measure of $w_{k}$, defined as (total revenue minus variable cost)/equity capital). Such measure is more consistent with the single-product cost function associated with the bank's primary activity of lending. ${ }^{48}$ Table 11 reports in the parentheses beneath the $R O A E s$ the values of $w_{k}$, calculated by size of banks and financial systems. The average value for $w_{k}$ over total sample observations is 0.08 , which is lower by 0.03 point than the $R O A E(0.11)$. Interestingly, the average value of $w_{k}$ in medium size banks $(0.10)$ and medium size systems $(0.11)$ is the highest of their respective classes. It can be observed that, on the whole, $w_{k}$ appears to be consistently smaller than the $R O A E$ across different classes of bank and system size. ${ }^{49}$

Table 11. Opportunity Cost of Financial Capital (ROAE and $w_{k}$ ) by Size of Banks and Financial Systems

\begin{tabular}{|c|c|c|c|c|}
\hline Financial & & & & \\
System & & & & Total \\
Size $(F S)$ & Small & Medium & Large & \\
& & & & \\
\hline Bank Size $(t a)$ & & & & 0.13 \\
\hline \multirow{2}{*}{ Small } & 0.15 & 0.18 & 0.12 & $(0.07)$ \\
\hline Medium & $(0.02)$ & $(0.12)$ & $(0.08)$ & 0.11 \\
& 0.19 & 0.16 & 0.10 & $0.10)$ \\
\hline \multirow{2}{*}{ Large } & $(0.05)$ & $(0.14)$ & $(0.09)$ & $(0.10)$ \\
& 0.12 & 0.16 & 0.08 & 0.08 \\
& $(0.00)$ & $(0.05)$ & $(0.07)$ & $(0.07)$ \\
\hline \multirow{2}{*}{ Total } & 0.15 & 0.16 & 0.10 & 0.11 \\
& $(0.03)$ & $(0.11)$ & $(0.08)$ & $(0.08)$ \\
\hline
\end{tabular}

Notes: 1) All are 1995-97 mean values of $R O A E$ and $w_{k}$ for each subgroup.

2) The figures in parenthesis denote computed market rental price of financial capital $\left(w_{k}\right)$.

${ }^{48}$ The reported values of $R O A E$ reflect the final result of all kinds of banking activities, including non-interest operating income (fees, commissions, etc.), as well as extraordinary income. Since our cross-sectional study was limited by data availability, we assumed a single-product (loans) cost function, instead of multi-product cost function, allowing us to focus on the primary banking activities of lending and deposit. Since the underlying single output specification is different from that of the multi-output associated with other nonbanking opcrating activities, determining the appropriate rate of return on a single-product activity and using it as a proxy for the price of financial capital required us to adjust the normal operating income accordingly. In the literature, the operating income derived as a residual by subtracting expenses from revenue can be attributed to the contribution of the quasi-fixed factor input of capital, after allocating the relative income share of variable factor inputs. Consequently, our model specification requires that we use an adjusted measure of market rental price of equity capital $\left(w_{k}\right)$, rather than the unadjusted $R O A E$. Considering the basic setup of a cost function where the output price $P$ (lending rate of interest) was constructed by dividing total interest income by total loans $(Q)$, the market rental price of capital can be obtained by dividing the operating surplus by the equity capital, $(P Q-V C) / k$.

\footnotetext{
${ }^{49}$ A possible explanation for the systematically lower values is that most of the sample banks largely operate in non-interest income activity areas. Since we assume a single-product function (see previous footnote), the associated total (interest) income is smaller than the income associated with a multi-product function.
} 
In order to investigate whether the level of financial capital changes systematically with financial system size, we also need a shadow measure of the price of capital $\left(w_{k}^{*}\right)$, which can be analytically derived from the restricted variable cost function (i.e., $\partial C_{V} / \partial k$ ), thus enabling us to compare whether $w_{k}$ is greater than $w^{*}$. Table 12 reports the average value of $w_{k}^{*}$ obtained by calculating the realized value of $\left(\partial C_{V} / \partial k\right)$. As shown in the table, the marginal (or shadow) cost of financial capital is negative both in medium $(-0.036)$ and large $(-0.110)$ systems, while it is positive in small systems (0.074). If we interpret the marginal cost of financial capital as representing the cost incurred by banks to signal their strength to the market (Hughes and Mester, 1998), our results seem to suggest that there are system-dependent scale efficiency effects in the cost of financial capital. As argued earlier, this may be due to the higher efficiency of information provision and signaling that characterize larger systems vis-a-vis smaller ones.

Table 12. Marginal (Shadow) Cost of Financial Capital $\left(\partial C_{V} / \partial k\right)$ by Size of Banks and Financial Systems

\begin{tabular}{|c|c|c|c|c|}
\hline $\begin{array}{c}\text { Financial } \\
\text { System } \\
\text { Size }(F S)\end{array}$ & Small & Medium & Large & Total \\
\hline Bank Size $(t a)$ & & & & \\
\hline Small & 0.070 & -0.035 & -0.120 & -0.085 \\
\hline Medium & 0.110 & -0.038 & -0.130 & -0.110 \\
\hline Large & 0.000 & -0.035 & -0.092 & -0.086 \\
\hline Total & 0.074 & -0.036 & -0.110 & -0.094 \\
\hline
\end{tabular}

Notes: 1) All are 1995-97 mean values for each subgroup.

Finally, comparing the equilibrium price $\left(w_{k}\right)$ in Table 11 with the marginal (shadow) cost of financial capital $\left(w_{k}^{*}\right)$ in Table 12 gives an indication of the degree of utilization of financial capital by banks: if the marginal cost exceeds (is lower than) the equilibrium price, financial capital is being over- (under-) utilized, while their equality indicates optimal utilization. This comparison is reported in Table 13. 
Table 13. Utilization of Financial Capital by Size of Banks and Financial Systems

\begin{tabular}{|c|c|c|c|c|}
\hline $\begin{array}{c}\text { Financial } \\
\text { System } \\
\text { Size }(F S)\end{array}$ & Small & Medium & Large & Total \\
\hline Bank Size $(t a)$ & & & & \\
\hline Small & 0.086 & 0.083 & -0.043 & -0.013 \\
\hline Medium & 0.160 & 0.110 & -0.038 & -0.014 \\
\hline Large & 0.120 & 0.018 & -0.023 & -0.019 \\
\hline Total & 0.100 & 0.075 & -0.034 & -0.015 \\
\hline
\end{tabular}

Notes: 1) The figures are obtained from $\left(w_{k}+\partial C_{V} / \partial k\right)$.

Positive (negative) values indicate over-utilization (under-utilization).

2) All are 1995-97 mean values for each subgroup.

Notice from Table 12 that the marginal cost of financial capital observed over the whole sample is negative $(-0.094)$, implying that financial capital is an efficient riskmanagement instrument and signaling device for banks: a higher level of capital indicates a lower risk and reduces the equilibrium market price of capital, signifying a lower risk. However, this does not hold for banks in small financial systems.

The observed utilization of financial capital, estimated by size of banks and financial systems (Table 13), suggests that banks over-utilize capital in small and medium size systems, while they under-utilize it in large systems. Only the large banks in the large systems operate close to an optimal capital range (the overall mean value of $\left(w_{k}+\partial C_{V} / \partial k\right)$ is $-0.034)$.

\section{Conclusion}

Based on the general assumption that finance involves increasing returns to scale of various sorts, this study has formulated and tested empirically the systemic scale economies (SSEs) hypothesis, whereby the production efficiency of financial intermediation increases with the size of the system where it takes place. Using a large cross-country and time-series banking data panel, the study has shown that intermediaries operating in systems with large markets and infrastructures have lower production costs and lower costs of risk absorption and reputation signaling than intermediaries operating in small systems. The study has explored different channels through which the SSEs work their effects on intermediaries, and has derived statistically significant estimates of such effects. In particular, the results show that

- SSEs can be detected when risk is endogenized in bank production decisions, and banks are modeled as value-maximizing agents. 
- Larger, deeper, and more efficient financial systems enable banks to save on the resources needed to manage the higher risks associated with larger production.

- Small banks in large systems are more cost efficient than small banks in small systems.

- The cost-efficiency effects of technological changes are more rapid for banks operating in larger systems.

- Banks in small (large) systems tend to over- (under-)utilize financial capital, while large banks in large systems operate at an approximately optimal capital level.

More generally, one may conclude that the minimum size for a bank to be market viable decreases with the size of the financial system where it operates. As a consequence, stronger competition (or lower market concentration) can fully translate into higher scale efficiency for individual banks only in system size above a certain threshold level.

The results have also shown that information transparency and institutional development (that is, better financial infrastructure) allow intermediaries achieve considerable scale efficiency gains.

The evidence produced by this study has shown that the financial intermediaries in small systems operate at a comparative disadvantage with respect to those operating in larger systems. The evidence supports the intuition underpinning the work by Bossone, Honohan and Long (2001) and strengthens the case for their policy recommendations. 


\section{Classification of Countries by Size of Their Financial Systems}

\begin{tabular}{|c|c|c|c|c|c|c|c|}
\hline & \multirow[b]{2}{*}{ Country } & \multicolumn{2}{|c|}{$\begin{array}{c}\text { Absolute Size of } \\
\text { System }\end{array}$} & \multicolumn{2}{|c|}{$\begin{array}{c}\text { Relative Size of } \\
\text { System }\end{array}$} & \multicolumn{2}{|c|}{ Institutions \& Market } \\
\hline & & $\begin{array}{c}F S^{2)} \\
\text { (in bil U\$) } \\
\end{array}$ & $\begin{array}{c}M 2 \\
\text { (in bil U\$) } \\
\end{array}$ & \begin{tabular}{c|}
$F S D^{3)}$ \\
$(\%)$ \\
\end{tabular} & $\begin{array}{c}M S^{4)} \\
(\%) \\
\end{array}$ & $\begin{array}{c}A S^{5)} \\
(100.0) \\
\end{array}$ & $\begin{array}{c}C N^{6)} \\
(1.000) \\
\end{array}$ \\
\hline Small & Estonia & 3.8 & 1.3 & 40.8 & 0.33 & 54.9 & 0.765 \\
\hline Financial & Jamaica & 5.3 & 2.4 & 50.4 & 0.15 & 55 & 0.812 \\
\hline \multirow[t]{23}{*}{ System } & Ethiopia & 6.4 & 2.6 & 52.5 & 0.88 & 42.7 & 1.000 \\
\hline & Trinidad and Tobago & 6.7 & 2.5 & 58.9 & 0.01 & 63 & 0.745 \\
\hline & Mauritius & 6.9 & 3.2 & 83.8 & 0.03 & 54.9 & 0.922 \\
\hline & Ecuador & 7.5 & 6.2 & 19.8 & 0.01 & 46 & 0.367 \\
\hline & Costa Rica & 7.7 & 3.7 & 31.8 & 0.00 & 47 & 0.732 \\
\hline & Dominican Republic & 7.9 & 3.7. & 29.4 & 0.14 & 32 & 0.583 \\
\hline & Iceland & 8.3 & 2.7 & 56.9 & 0.02 & 63 & 0.781 \\
\hline & Nigeria & 10.7 & 4.8 & 16.4 & 0.00 & 42.7 & 0.742 \\
\hline & Oman & 11.9 & 4.3 & 41.4 & 3.04 & 54.9 & 0.642 \\
\hline & Bahrain & 12.3 & 3.8 & 110.2 & 1.21 & 54.9 & 0.931 \\
\hline & Sri Lanka & 12.8 & 4.6 & 46.2 & 0.01 & 55 & 0.781 \\
\hline & Malta & 14.0 & 4.8 & 210.9 & 0.00 & 47 & 0.937 \\
\hline & Qatar & 15.5 & 5.5 & 88.2 & 27.14 & 65.7 & 0.932 \\
\hline & Romania & 19.6 & 8.4 & 30.2 & 0.00 & 50.6 & 0.798 \\
\hline & Slovenia & 20.1 & 7.3 & 54.0 & 0.05 & 65.7 & 0.644 \\
\hline & Croatia & 21.2 & 6.4 & 56.3 & 0.01 & 54.9 & 0.654 \\
\hline & Jordan & 21.5 & 7.0 & 152.6 & 0.42 & 50.6 & 0.911 \\
\hline & Tunisia & 23.8 & 9.0 & 63.4 & 0.01 & 50.6 & 0.519 \\
\hline & Bangladesh & 26.2 & 11.8 & 32.5 & 0.03 & 24 & 0.598 \\
\hline & Cyprus & 30.7 & 8.3 & 176.4 & 0.18 & 55 & 0.829 \\
\hline & Slovak Republic & 32.4 & 12.8 & 82.8 & 0.99 & 54.9 & 0.807 \\
\hline & Peru & 35.0 & 13.7 & 31.1 & 0.54 & 38 & 0.620 \\
\hline & (Average) & 15.3 & 5.9 & 67.36 & 1.47 & 50.96 & 0.752 \\
\hline Medium & Algeria & 39.0 & 17.5 & 43.1 & 0.14 & 50.6 & 1.000 \\
\hline Financial & Lebanon & 47.8 & 18.3 & 182.1 & 0.03 & 54.9 & 0.381 \\
\hline \multirow[t]{14}{*}{ System } & Venezuela, RB & 55.6 & 17.6 & 35.4 & 0.14 & 40 & 0.507 \\
\hline & Pakistan & 62.6 & 28.5 & 50.2 & 1.59 & 47 & 0.630 \\
\hline & Kuwait & 66.1 & 24.8 & 113.5 & 64.79 & 65.7 & 0.684 \\
\hline & Hungary & 67.0 & 18.8 & 74.2 & 1.41 & 54.9 & 0.585 \\
\hline & Colombia & 69.7 & 20.6 & 35.1 & 0.02 & 50 & 0.369 \\
\hline & United Arab Emirates & 80.6 & 23.7 & 86.2 & 27.14 & 65.7 & 0.600 \\
\hline & Chile & 92.4 & 29.4 & 66.2 & 1.77 & 52 & 0.416 \\
\hline & Czech Republic & 100.6 & 40.2 & 92.8 & 1.43 & 54.9 & 0.645 \\
\hline & Poland & 110.0 & 46.0 & 42.0 & 0.22 & 54.9 & 0.399 \\
\hline & Philippines & 135.8 & 45.1 & 84.6 & 7.08 & 65 & 0.458 \\
\hline & New Zealand & 142.0 & 55.1 & 111.9 & 2.45 & 70 & 0.616 \\
\hline & Turkey & 156.7 & 64.5 & 43.2 & 8.99 & 50.6 & 0.404 \\
\hline & Argentina & 184.8 & 63.7 & 33.5 & 0.14 & 45 & 0.324 \\
\hline & Israel & 190.4 & 78.2 & 99.4 & 1.01 & 64 & 0.600 \\
\hline
\end{tabular}




\begin{tabular}{|c|c|c|c|c|c|c|c|}
\hline & Finland & 200.5 & 67.6 & 79.2 & 5.12 & 77 & 0.928 \\
\hline & Saudi Arabia & 209.2 & 69.6 & 75.6 & 0.68 & 54.9 & 0.507 \\
\hline & Norway & 251.3 & 83.5 & 82.0 & 6.15 & 74 & 0.814 \\
\hline & Greece & 254.4 & 56.4 & 105.1 & 1.46 & 55 & 0.756 \\
\hline & Malaysia & 257.0 & 89.1 & 132.5 & 174.49 & 76 & 0.397 \\
\hline & Ireland & 266.1 & 42.9 & 180.3 & 4.53 & 71 & 0.604 \\
\hline & Indonesia & 274.0 & 111.8 & 63.6 & 2.23 & 42.7 & 0.359 \\
\hline & South Africa & 296.3 & 76.4 & 100.2 & 6.25 & 70 & 0.362 \\
\hline & Portugal & 298.5 & 80.0 & 137.6 & 1.80 & 36 & 0.453 \\
\hline & (Average) & 156.3 & 50.8 & 86.0 & 12.8 & 57.7 & 0.552 \\
\hline Large & Denmark & 316.3 & 103.5 & 89.4 & 4.94 & 62 & 0.727 \\
\hline Financial & Singapore & 322.1 & 78.4 & 178.7 & 37.97 & 65.7 & 0.646 \\
\hline \multirow[t]{22}{*}{ System } & India & 340.0 & 176.5 & 44.5 & 0.55 & 57 & 0.553 \\
\hline & Thailand & 476.6 & 139.5 & 143.8 & 6.06 & 64 & 0.502 \\
\hline & Sweden & 580.3 & 114.4 & 117.7 & 35.75 & 83 & 0.861 \\
\hline & Brazil & 631.0 & 220.2 & 41.5 & 3.27 & 54 & 0.402 \\
\hline & Australia & 668.9 & 253.2 & 82.5 & 11.98 & 75 & 0.563 \\
\hline & Korea & 669.1 & 211.7 & 67.7 & 9.42 & 62 & 0.257 \\
\hline & Austria & 693.9 & 61.0 & 154.6 & 1.15 & 54 & 0.722 \\
\hline & $\begin{array}{l}\text { Luxembourg } \\
\text { Taiwán Province of }\end{array}$ & $1,001.2$ & 13.0 & 27849 & 0.07 & 65.7 & 0.386 \\
\hline & China & $1,029.3$ & 380.2 & 185.0 & 1,32684 & 65 & 0.362 \\
\hline & Canada & $1,103.9$ & 364.8 & 91.6 & 22.62 & 74 & 0.587 \\
\hline & Belgium & $1,197.9$ & 81.3 & 228.4 & 0.97 & 61 & 0.690 \\
\hline & Spain & $1,284.9$ & 254.8 & 110.1 & 30.47 & 64 & 0.491 \\
\hline & Netherlands & $1,320.7$ & 181.6 & 165.1 & 57.31 & 64 & 0.702 \\
\hline & Switzerland & $1,430.0$ & 386.1 & 251.2 & 243.34 & 68 & 0.797 \\
\hline & Hong Kong SAR & $1,792.6$ & 270.3 & 582.3 & 328.71 & 65.7 & 0.601 \\
\hline & Italy & $2,133.5$ & 539.4 & 91.6 & 1.58 & 62 & 0.354 \\
\hline & France & $3,987.9$ & 642.7 & 132.8 & 7.94 & 69 & 0.440 \\
\hline & Germany & $5,837.1$ & 795.2 & 126.3 & 16.31 & 62 & 0.472 \\
\hline & United Kingdom & $5,938.5$ & 612.3 & 245.6 & 37.50 & 78 & 0.504 \\
\hline & United States & $13,125.4$ & $4,513.2$ & 84.2 & 108.27 & 71 & 0186 \\
\hline & Japan & $20,467: 2$ & 52558 & 220.2 & 6.48 & 65 & 0.226 \\
\hline & (Average) & 2884.7 & 680.4 & 270.4 & 100.0 & 65.7 & $\overline{0.523}$ \\
\hline $\begin{array}{l}\text { Others } \\
\text { (Small } \\
\text { Open) }\end{array}$ & $\begin{array}{l}\text { Bermuda } \\
\text { Liechtenstein } \\
\text { Monaco }\end{array}$ & 0.7 & - & 15.4 & 27.14 & 65.7 & 1.000 \\
\hline \multicolumn{2}{|c|}{ Average over 75 Total Countries } & 967.5 & 233.7 & 137.1 & 36.5 & 58.3 & 0.625 \\
\hline
\end{tabular}

Notes: 1) All figures represent the three year average during 1995-97.

2) $F S=$ Domestic Credit + Demand Deposits + Foreign Assets + Foreign Liabilities

3) $F S D=F S / G D P^{*} I 00$

4) $M S=($ stock market capitalization $/ G D P) \times($ stock market total value traded/GDP $) \times($ stock market turnover/GDP)*100

5) $A S$ : Accounting Standards Index for information transparency $(0<A S<100)$

6) $C N$ : Banking market concentration index $(0<C N<1)$

7) Shaded area above refers to the biggest (or smallest for $C N$ ) value in each column of the Table. 


\section{REFERENCES}

Allen, F., and D. Gale, 1999, Comparing Financial Systems (Cambridge, Massachussets: MIT Press).

Allen, F., and D. Gale, 2002, "Banking and Markets", presented at the IMF seminar on financial issues jointly held by the Monetary and Exchange Affairs and Research Departments seminar, March 5, 2002.

Allen, F., and A. Santomero, 2001, "The Theory of Financial Intermediation", Journal of Banking and Finance, 25, 2, pp. 271-94.

Altunbas, Y., E. P. M. Gardener, P. Mulineaux, and B. Moore, 2001, "Efficiency in European Banking", European Economic Review, 45, pp. 1931-1955.

Altunbas, Y., and P. Molyneux, 1996, "Economies of Scale and Scope in European Banking", Applied Financial Economics, 6, pp. 367-75.

Barth, J., G. Caprio Jr. and R. Levine, "Banking Systems Around the Globe: Do Regulation and Ownership Affect Performance and Stability?", forthcoming in Prudential Regulation and Supervision: Why Is It Important and What Are the Issues?, edited by F. Mishkin (Cambridge, Massachussets: National Bureau of Economic Research).

Bauer, P. W., and G. D. Ferrier, 1996, "Scale Economies, Cost Efficiencies, and Technological Change in Federal Reserve Payments Processing", Journal of Money, Credit, and Banking, 28, pp.1004-39.

Beck, T., A. Demirgüç-Kunt, and R. Levine, 1999, "A New Database on Financial Development and Structure", Financial Sector Discussion Paper No. 2 (Washington: World Bank).

Belton, T. M., 1984, "Economies of Scale in Book-Entry Securities", unpublished (Washington: Board of Governors of the Federal Reserve System).

Berger, A. N., 1998, "The Efficiency Effects of Bank Mergers and Acquisitions: A Preliminary Look at the 1990s Data", in Bank Mergers and Acquisitions, edited by Y. Amihud and G. Miller (Dordrecht: Kluwer Academic Publishers), pp. 79-111.

, and L. J. Mester, 1997, "Inside the Black Box: What Explains Differences in the Efficiencies of Financial Institutions", Journal of Banking and Finance, 20, pp. 895-947.

, L. J. Mester, and P. E. Strahan, 1999, "The Consolidation of the Financial Services Industry: Causes, Consequences, and Implications for the Future", Journal of Banking and Finance, 23, 2-4, pp. 135-94.

Berndt, E. R. Hall, B. E., and J. A. Hausman, 1974, "Estimation and Inference in Nonlinear Structural Models", Annals of Economic and Social Measurement, 3, pp. 653-65. 
Biller, M. T., M. J. Flannery, and J. A. Garfinkel, 1995, "The Effect of Lender Identity on a Borrowing Firm's Equity Return", Journal of Finance, 50, pp. 699-718.

Bossone, B., 2001a, "Circuit Theory of Banking and Finance", Journal of Banking and Finance, 25, 5, pp. 857-90.

, 2001b, "Do Banks Have a Future? A Study on Banking and Finance As We Move Into the Third Millennium", Journal of Banking and Finance, 25, pp. 2239-2276.

Bossone, B., P. Honohan, and M. Long, 2001, "Policy for Small Financial Systems", Financial Sector Discussion Paper 6 (Washington: World Bank).

Calem, P. S., 1994, "The Impact of Geographic Deregulation on Small Banks", Business Review, Nov./Dec. (Philadelphia: Federal Reserve Bank of Philadelphia).

Chong, B. S., 1991, "The Effects of Interstate Banking on Commercial Banks' Risk and Profitability", Review of Economics and Statistics, 73, pp. 78-84.

Claessens, S., A. Demirguç-Kunt, and H. Huizinga, 2001, "How Does Foreign Entry Affect the Domestic Banking Market?", Journal of Banking and Finance, 25, pp. 891-911.

, and J. K. Lee, 2002, "Foreign Banks in Low-Income Countries: Recent

Developments and Impacts", background paper for the Global Development Finance 2002 (Washington: World Bank)

Corrigan, E. G., 1982, "Are Banks Special?", Annual Report Essay (Minneapolis: Federal Reserve Bank of Minneapolis). ,2000, "Are Banks Special? A Revisitation", The Region (Special Issue) (Minneapolis: Federal Reserve Bank of Minneapolis).

Cummins, J. D., and M. A. Weiss, 1993, "Measuring Cost Efficiency in the PropertyLiability Insurance Industry", Journal of Banking and Finance, 17, pp. 463-81.

Cybo-Ottone, A., C. Di Noia, and M. Murgia, 1999, "The Consolidation of Securities Exchanges. Is There Any Lesson from the European Experience?", unpublished.

Das, A., 1998, "Portfolio Risks and Scale Economies in Banking: The Indian Case", International Journal of Development Banking, 16, 2, pp. 3-12.

Demirguc-Kunt, A., and H. Huizinga, 1999, "Determinants of Commercial Bank Interest Margins and Profitability: Some International Evidence", The World Bank Economic Review, 13, 2, pp. 379-408. , and R. Levine, 1996, "Stock Market Development and Financial Intermediary Growth: Stylized Facts", World Bank Economic Review, 10, 2. 
,2000, "Bank-Based and Market-Based Financial Systems: Cross-Country

Comparisons", unpublished.

, (eds.), 2001, Financial Structure and Economic Growth. A Cross-Country

Comparison of Banks, Markets, and Development (Cambridge, Massachussets: MIT Press).

Demsetz, R. S., and P. E. Strahan, 1997, "Diversification, Size, and Risk at Bank Holding Companies", Journal of Money, Credit, and Banking, 29, pp. 300-13.

Dermine, J., and L. Röller, 1992, "Economies of Scale and Scope in French Mutual Funds", Journal of Financial Intermediation, 2, pp. 83-93.

De Young, R., J. P. Hughes, and C. G. Moon, 1998, "Regulatory Covenant Enforcement and the Efficiency of Risk-Taking at U.S. Commercial Banks", Economics Working Paper 98-1 (Washington: Office of the Comptroller of the Currency).

Diamond, D., 1997, “Liquidity, Banks, and Markets”, Journal of Political Economy, 105(5), pp. 928-56.

Drake, L., 1992, "Economies of Scale and Scope in UK Building Societies: An Application of the Translog Multiproduct Cost Function”, Applied Financial Economics, 2, pp. 211-19.

Fecher, F., S. Perelman, and P. Pastieau, 1992, "Scale Economies and Performance in the French Insurance Industry”, International Journal of Industrial Organization, 3, pp. 345-61.

Focarelli, D., 1992, "Economie di Scala e della Diversificazione Produttiva nel Settore Assicurativo Italiano", Rivista di Politica Economica, April, pp. 23-44.

Franks, J. R., S. M. Schaefer, and M. D. Staunton, 1998, "The Direct and Compliance Costs of Financial Regulation", Journal of Banking and Finance, 21, pp. 1547-1472.

Fried, H. O., C. A. Knox Lovell, and P. Vanden Eckaut, 1993, "Evaluating the Performance of U.S. Credit Unions", Journal of Banking and Finance, 17, pp. 251-65.

Fukuyama, H., 1993, "Technical and Scale Efficiency of Japanese Commercial Banks: A Non-Parametric Approach", Applied Economics, 25, pp. 1101-12.

Fukuyama, H., and W. L. Weber, 1999, "The Efficiency and Productivity of Japanese Securities Firms, 1988-93", Japan and the World Economy, 11, pp. 115-33.

Ghilarducci, T., and K. Terry, 1999, "Scale Economies in Union Pension Plan Administration", Industrial Relations, 38, 1, pp.11-17.

Glaessner, T, and S. Valdés-Prieto, 1998, "Pension Reform in Small Developing Countries", Policy Research Working Paper No. 1983 (Washington: World Bank). 
Gowrisankaran, G., and J. Stavins, 1999, "Network Externalities and Technology Adoption: Lessons from Electronic Payments", Working Paper 99-5, (Boston: Federal Reserve Bank).

Green, C. J., P. Maggioni, and V. Murinde, 2000, "Regulatory Lessons for Emerging Stock Markets from a Century of Evidence on Transactions Costs and Share Price Volatility in the London Stock Exchange", Journal of Banking and Finance, 24, 4, pp. 577-602.

Gropper, D. M., 1991, "An Empirical Investigation of Changes in Scale Economies for the Commercial Banking Firm, 1979-1986", Journal of Money, Credit and Banking, 23, 4, pp. 718-27.

Hancock, D., D. B. Humphrey, and J. A. Wilcox, 1999, "Cost Reductions in Electronic Payments: The Roles of Consolidation, Economies of Scale, and Technical Change", Journal of Banking and Finance, 23, pp. 391-421.

Hasan, I., and M. Malkamäki, 2001, "Are Expansions Cost Effective for Stock Exchanges? A Global Perspective", Journal of Banking and Finance, 25, pp. 2339-2366.

Honohan, P., 2000, "Banking System Failures in Developing and Transition Countries: Diagnosis and Prediction", Economic Notes, 29, 1, pp. 83-109.

, and R. P. Kinsella, 1982, "Comparing Bank Concentration Across Countries", Journal of Banking and Finance, 6, pp. 255-62.

Hopkins, T. D., 1992, "The Cost of Federal Regulation", Journal of Regulation and Social Costs, 2, 1.

Hughes, J. P., 1999, "Incorporating Risk into the Analysis of Production", American Economic Journal, 27, pp. 1-23.

Hughes, J. P., and L. J. Mester, 1998, "Bank Capitalization and Cost: Evidence of Scale Economies in Risk Management and Signaling", Review of Economics and Statistics, 80, 2, pp. 314-25.

Hughes, J. P., W. Lang, L. J. Mester, and C. G. Moon, 1997, "Recovering Risky Technologies Using the Almost Ideal Demand System: An Application to U.S. Banking", unpublished.

, 1999a, "Efficient Banking Under Insterstate Branching", Review of Economics and Statistics, 81, pp. 250-60.

, 1999b, "The Dollars and Sense of Bank Consolidation", Journal of Banking and Finance, 23, pp. 291-324.

, 2001, "Are Scale Economies in Banking Elusive or Illusive? Evidence Obtained by Incorporating Capital Structure and Risk-Taking into Models of Bank Production", Journal of Banking and Finance, 25, 12, pp. 2169-208. 
IBCA, 2000, BvD Suite's BankScope Database, CD-Rom version and periodically updated website versions.

IMF, 2001, International Financial Statistics, various issues (Washington DC).

Jacklin, C., 1987, "Demand Deposit, Trading Restrictions and Risk Sharing", in Contractual Arrangements for Intertemporal Trade, edited by E. Prescott and N. Wallace (Minneapolis: University of Minnesota Press).

Jacklin, C., and S. Bhattacharya, 1988, "Distinguishing Panic and Information Based Bank Runs: Welfare and Policy Implications”, Journal of Political Economy, 96, 3, pp. 568-92.

James, C., 1987, "Some Evidence on the Uniqueness of Bank Loans", Journal of Financial Economics, 19, pp. 217-35.

Karafolas, S., and G. Mantakas, 1996, "A Note on Cost Structure and Economies of Scale in Greek Banking”, Journal of Banking and Finance, pp. 377-87.

Katrishen, F. A., and N. A. Scordis, 1998, "Economies of Scale in Services: A Study of Multinational Insurers", Journal of International Business Studies, 29, 2, pp. 305-23.

Kohers, T., and D. Mullis, 1998, "An Update on Economies of Scale in Credit Unions", Applied Economics, 20, pp. 1653-59.

Kono, M., and L. Schucknecht, 1999, "Financial Services Trade, Capital Flows, and Financial Stability", unpublished (Geneva: Word Trade Organization).

Lang, G., and P. Welzel, 1996, "Efficiency and Technical Progress in Banking. Empirical Results for a Panel of German Cooperative Banks", Journal of Banking and Finance, 20, pp. 1003-23.

Le Compte, R., and S. Smith, 1990, "Changes in the Cost of Intermediation: The Case of Saving and Loans", Journal of Finance, 45, pp. 1337-46.

La Porta, R., F. Lopez-de-Silane, A. Shleifer, and R. Vishny, 1997, "Legal Determinants of External Finance", Journal of Finance, 52, 3, pp. 1131-50.

, 1998, "Law and Finance", Journal of Political Economy, 106, 6, pp. 1113-55.

Levine, R, N. Loayza, and T. Beck, 2000, "Financial Intermediation and Growth: Causality and Causes", Journal of Monetary Economics, 46, pp. 31-77.

Lummer, S. L., and J. J. McConell, 1989, "Further Evidence on the Bank Lending Process and the Capital-Market Response to Bank Loan Agreement", Journal of Financial Economics, 79, pp. 113-34. 
Malkamäki, M., 1999, "Are There Economies of Scale in Stock Exchange Activities?", Discussion Paper 4/99 (Helsinki: Bank of Finland).

McAllister, P. H., and D. A. McManus, 1993, "Resolving the Scale Efficiency Puzzle in Banking", Journal of Banking and Finance, 17, pp. 389-405.

Mehdian, S. M., and R. Rezvanian, 1998, "Production Economies of Small Depository Institutions in the Post-FIRREA Era: Evidence from Cooperative Banks", Applied Economics, 30, pp. 427-33.

Pallage, S. J., 1991, "An Econometric Study of the Belgian Banking Sector in Terms of Scale and Scope Economies", Cahiers Economiques de Bruxelles, No. 130.

Parigi, G., P. Sestito, and U. Viviani, 1992, "Economie di Scala e di Diversificazione nell'Industria Bancaria: Il Ruolo dell'Eterogeneità tra Imprese", Temi di Discussione, No. 174, July (Roma: Banca d'Italia).

Parisio, L., 1992, "Economies of Scale and Scope in the Italian Banking Industry: Evidence from Panel Data", Rivista Internazionale di Scienze Economiche e Commerciali, 39, 10-11, pp. 959-78.

Rezvanian, R., S. Mehdian, and E. Elyasiani, 1996, "Economies of Scale and Scope in Small Depository Institutions: Evidence from U.S. Cooperative Banks", The Quarterly Review of Economics and Finance, 36, 1, pp. 39-54.

Saloner, G., and A. Shepard, 1995, "Adoption of Technologies with Network Effects: An Empirical Examination of the Adoption of Automated Teller Machines", Rand Journal of Economics, 26, Autumn, pp. 479-501.

Simper, R., 1999, "Economies of Scale in the Italian Saving Bank Industry", Applied Financial Economics, 9, pp. 11-19.

Slovin, M. B., M. E. Sushka, and C. D. Hudson, 1988, "Corporate Commercial Paper, Note Issuance Facilities, and Shareholder Wealth", Journal of International Money and Finance, 7, pp. 289-302.

Suret, J. M., 1991, "Scale and Scope Economies in the Canadian Property and Casualty Insurance Industry", Geneva Papers on Risk and Insurance, 16, pp. 236-56.

Vander Vennet, R., 1994, "Economies of Scale and Scope in EC Credit Institutions", Cahiers Economiques de Bruxelles, No. 144, pp. 509-48.

Vasiliou, D., 1992, "Economies of Scale in Greek Commercial Banking: A First Endeavour", Rivista Internazionale di Scienze Economiche e Commerciali, 39, 10-11, pp. 79-89.

Walker, G., 1998, "Economies of Scale in Australian Banks 1978-1990", Australian Economic Papers, 37, 1, pp. 71-87. 
World Bank, 2001a, Global Development Finance (Washington DC).

World Bank, 2001b, World Development Indicators (Washington DC).

Yuengert, A. M., 1993, "The Measurement of Efficiency in Life Insurance: Estimates of a Mixed Normal-Gamma Error Model”, Journal of Banking and Finance, 17, pp. 483-96.

Zardkoohi, A., and J. Kolari, 1994, "Branch Office Economies of Scale and Scope: Evidence from Savings Banks in Finland", Journal of Banking and Finance, 18, pp. 421-32. 